\title{
GRUNDTVIG \\ OG DEN DANSKE RIMKRØNIKE
}

Af Helge Toldberg.

For de ældre generationer af Grundtvig-forskere var mærkeåret 1824 eller 1825, alt efter om de var litteraturhistorikere eller teologer. De første betragtede Nyaars-Morgen som en slutsten på Grundtvigs ungdomsdigtning, og kunne føle sig bekræftet heri ved at Grundtvig selv fjorten år senere havde betegnet dette år som »en Vendepunkt i mit Skjaldeløb«; dette skete i fortalen til Nordiske Smaadigte, det udvalg af egne digte Grundtvig 1838 udsendte i Christiania som særlig beregnet for norske læsere, som motivering for at han ingen digte havde medtaget der var yngre end 1824. Derimod følte teologerne sig naturligt bundet til 1825, året for den mageløse opdagelse og Kirkens Gienmæle; én litteraturhistoriker, Paul V. Rubow, har sluttet sig til dette standpunkt, i afhandlingen Det store Vendepunkt i Grundtvigs Liv (Smaa kritiske Studier, 1935, s. 7 ff.).

Med den generation af Grundtvig-forskere der kom i gang under og efter den anden verdenskrig, er der imidlertid ført en række omvurderinger til torvs, hvoraf nogle, som Henning Høirups påvisning af modsigelsens grundsætning som aksiom hos Grundtvig, må tilkendes absolut gyldighed, mens andre endnu henstår som individuelle vurderinger der på den ene side ikke kan betragtes som endeligt fastslået men på den anden side heller ikke kan holdes udenfor den videnskabelige diskussion. I den mundtlige Grundtvig-debat, ved møder i og udenfor Grundtvig-Selskabet, har et synspunkt Kaj Thaning oprindelig fremsatte i afhandlingen Et tredie Grundtvigstandpunkt (Tidehverv XV, 1941, s. $86 \mathrm{ff}$., $99 \mathrm{ff}$.) spillet en særlig rolle: at det egentlige mærkeår er 1832, det år Grundtvig adskiller det kirkelige og det folkelige. Det skal naturligvis ikke drøftes nærmere her, da Thanings store værk endnu ikke foreligger; men synspunktet bør haves in mente nedenfor hvor det kontateres at Grundtvig $\mathrm{i}$ sin gendigtning af rimkrøniken 1834 i kladden fjernede danskernes velsignelse som ætlinge af Jafet, men i den trykte form tog den med! 
En større forberedende afhandling til sin bog, Grundtvigs Møde med Irenæus, i Grundtvig-Studier 1953, slutter Thaning (s. 67) med at polemisere mod det årstal, 1815, hvorfra jeg i min disputats, Grundtvigs symbolverden (1950), har fundet det forsvarligt at læse Grundtvigs forfatterskab som én bog. Dette årstal er bestemt af offentliggørelsen af Et Blad af Jyllands Rimkrønike. Ganske vist henviser Thaning til fortalen i Heimdall, hvoraf det fremgår at det er digtet 1814, og jeg skal indrømme at dette burde have været præciseret i Gr.symb., men til gengæld burde Thaning have nævnt at det af samme fortale fremgår at digtet er omarbejdet i 1815.

Denne omarbejdelse synes nemlig ikke at have været så helt ringe. Det er kun lidt vi har bevaret (i fasc. 387 i Grundtvig-arkivet på det kgl. bibl.) af digtets urform, men dette lidet giver en fornemmelse af en betydelig omkalfatring, uden at det naturligvis er muligt at skønne over om denne er sket 1814 eller 1815. Foruden det kladdemateriale Sv. Grundtvig optrykker, Poetiske Skrifter IV ${ }^{1}$ ) s. 1-3, findes der nogle blade (fasc. $387 \mathrm{bl} .213 \mathrm{ff}$.) som indeholder de sidste tre linjer af strofe 199, stroferne 200-202, 263-264 (sidstnævntes 3 sidste linjer anderledes end de nuværende) + endnu ni, senere opgivne, strofer, der slutter midt på en højreside $(217 \mathrm{r})$; det virker som en foreløbig slutning på et meget kortere digt end det endelige. Hovedafsnittet der siden blev udfyldt mellem str. 202 og str. 263, er skildringen af Ansgars gerning i Danmark (til og med str. 240); men sagligt vigtigst er på den ene side stroferne 223-30, hvor ravspejlet skildres som danskernes redskab til at opfatte historien med (jf. Gr.symb. s. $61 \mathrm{f}$.), og 247-249, der bebuder Israels og Dans trolovelse og, med Grundtvigs typiske associativitet (jf. min ældre bog, Grundtvig som filolog (1946) 1. kap.), gør Dan til en israelitisk stamme.

Disse to ting, som under alle omstændigheder er yngre end den første slutning på Et Blad af Jyllands Rimkrønike, gør dette digt skelsættende i Grundtvigs forfatterskab. Det første skal jeg her ikke gå nærmere ind på, fordi 4. kapitel i Gr.symb. er viet en indgående redegørelse for de to særgrundtvigske strukturer gåde og spejl. Det andet mener jeg derimod skal ses som en konsekvens af Grundtvigs

1) Foruden i PS IV, med den behagelige strofenumerering, er digtet fuldstændigt optrykt i Udvalgte Skrifter III, hvor også Begtrup fremhæver det som et nybrud i Gr.s forfatterskab (s. 143) : »Han taler første Gang, i lyse, milde Toner, om Danmarks Vætte og hylder Danmark som den kære Moder.« - I det seneste optryk, i Værker i Udvalg VII, er overspringelserne ødelæggende; bl. a. savnes næsten hele Amleth-afsnittet. 
bekendtskab med den danske rimkrønike, hvor det i Humbles rim siges at danskerne har del i deres stamfader Jafets velsignelse fra det øjeblik han bedækkede sin fars skam (jf. ndf.), selv om det var forberedt i Grundtvigs læsning af Lyschander i barndommen og senere, som William Michelsen så grundigt behandler i sin disputats, Tilblivelsen af Grundtvigs historiesyn (1954), dog med rigelig sikkerhed i sit forbehold s. 103: »Gr. har næppe som voksen mand anset det for muligt at rekonstruere Danmarks historie tilbage til syndfloden eller verdens skabelse.« Materialet nedenfor fra fasc. 288 tyder netop på at Grundtvig bekræftedes heri ved sit rimkrønikestudium.

Udenfor det beskedne kladdemateriale til Et Blad af Jyllands Rimkrønike er vi henvist til at gisne om omarbejdelser og overarbejdelser, og der er ikke andet at gøre end at efterprøve den logiske overensstemmelse $\mathrm{i}$ de enkelte afsnit. Der er i så henseende navnlig ét punkt der er grund til at rette sin mistanke mod, afsnittet om Amleth $^{2}$ ). I sagnet om ham er nemlig Grundtvig, modsigelsens energiske bekæmper, kommet til at lægge to modsatte holdninger for dagen. I str. 59 tales frisk og frejdig om »Hvordan den vakkre Jydeknøs, / Trak Rus omkap med Fenge«; men i str. 64 udlægges Amleths sønneløshed med bebrejdende ord:

Det er, naar Løven vorder snild ${ }^{3}$ ),

Vist paa de høie Navler,

Naar Løven driver Abespil,

Den ingen Løver avler.

Her er det nødvendigt at undersøge hvilken af de to holdninger, den frejdige eller den bebrejdende, der er ældst, og det er vi så heldige at kunne svare på, idet str. 57 og et enkelt ord i 58, der tydeligt hører til det frejdige lag i digtet, hentyder til november måned, og

2) Grundtvig bruger altid Saxos navneform, aldrig Hamlet.

3) Af Paul Diderichsen forklaret: »naar kongeslægtens heltemod afløses af Amleths snedighed ( Ordbog over det danske Sprog XIV, 1933, sp. 857). Tanken er udtrykt på en lidt anden måde Gr. symb. s. 150 f.: »den løve, som opgiver sin natur som det ondes bekæmper, svækker sig utilbørligt til den kamp med dragen og ornene, den altid skal være beredt til.« For Grundtvig i 1814-15 er det forklarligt, men ikke formildende, at Amleth griber til denne taktik for at dække sig mod »Tigren«, hans farbror Fenge, der har slået hans far, løven, ihjel (jf. Gr. symb. s. 55); på sine gamle dage så han mildere på det og kunne bruge str. 51-52 som »huskevers« i stykket om Amleth i Mundsmag af Danmarks Krønike til Levende Skolebrug (1842, s. 14). 
til at det »i Aar«, d.v.s. i 1815 (fortalen til Heimdall er dateret ${ }^{18} / 12$ ), er for sent at slå over $i$ en muntrere tone:

\author{
For Verdslighed og Lapperie \\ I Aar det blev for silde, \\ Thi Mortens-Dag er alt forbi, \\ Og Man fik intet Gilde, \\ En Smule her jeg peger paa \\ Kun for Umyndige og Smaa, \\ Som ikke er for Kloge. \\ Om Amleths Spil paa Kam og Aas, \\ Om Speideren der vilde \\ Ham slagtet som en Mortens-Gaas, \\ Men kom til Svine-Gilde, \\ Ja, blev og selv til Svinemad, \\ Derom jeg gierne rimet gad, \\ Men nu er det for silde.
}

Den første af stroferne frembyder ingen tolkningsvanskeligheder; den er en klar tilkendegivelse af hvilket publikum Grundtvig digter for: ikke de højlærde, men dem der i Bjergprædikenen kaldes de fattige $i$ ånden. Den anden strofe er for så vidt vanskeligere som den kræver nogen realkommentar, der må søges $i$ en af to kilder: rimkrøniken eller Vedels Saxooversættelse, der iøvrigt her som flere andre steder er ret påvirket af rimkrønikens sprogbrug. Vedels Saxo tør man altid trygt gætte på når benytteren er Grundtvig, men man undrer sig så over at denne benyttelse ikke har fundet sted fra første færd. Dels af denne grund, dels fordi Grundtvig ikke medtog Amleths rim, skønt hans yndlingsrim blandt sagnkongernes, i sit udvalg af rimkrøniken året efter i Dane-Virke $I$, er det rimeligt at regne med rimkrøniken som kilde da Grundtvig lagde sidste hånd på værket $\mathrm{i}$ november 1815 . Men som det direkte siges i str. 58, er det kommet så meget bag på ham at han ikke kan udtømme sin kilde, han må nøjes med nogle strejfglimt.

For at få mening i »Amleths Spil paa Kam og Aas« er vi, som sagt, nødt til at gå til en af de to mulige kilder, og vælger som den sandsynligste rimkrøniken. Baggrunden er episoden hvor det prøves om en kvinde kan lokke Amleth til at opføre sig normalt. Skønt de har gjort »hwer annens wiliæ«, lykkes det ham at få hende til at holde tand for tunge og præsentere Fenge for denne underfundige beskrivelse (v. 558-58, verstælling og ortografi her og i det følgende efter Molbechs optryk 1825 af Ghemenudgaven 1495): 
Wij loffue paa ryggaassen aff eth hwss, wij haffde ey klædher eller annen dwss ${ }^{4}$ ); Och sidhen paa en hanekom, oc paa hoffuen aff en hest wel from.

At Amleth skulle have været slagtet som en mortensgås, er et huskud bestemt af årstiden. Foruden triumfen i at det ikke lykkedes, er den barske humor et eksempel på den primitive realisme Grundtvig i dette digt for første gang optager fra folkelig digtning, men egentlig også fra Saxo og/eller rimkrøniken, hvis sadistiske udmaling (snarest rimkrønikens v. 589-94) resumeres når der tales om at spejderen kom til svinegilde og selv blev til svinemad:
Saa tog ieg karlen i halmen loo, och høg hannum all i støckæ smoo.
Saa kastæ ieg hannum meth handen myn
i gømmen eth hysken nedh for swyn.
Ther ode the hannum alsammen opp, med ben oc bruskæ, skynd oc kropp.

Ved sammenligning bemærkes både her og i de følgende strofer et hastigt, glimtvis udvalg af karakteristiske momenter, som efterlader et rids af hovedsituationerne og en jævnt fornøjet stemning over at det gik Fenge som fortjent. Hermed stemmer også at Amleths færd i str. 55-56 kaldes 》Jyllands Skiemte-Sage«. I str. 63 kobles imidlertid ind at sagnet har en skyggeside: Amleth faldt for frændehånd, og det fører over $i$ str. 64: kongeættens uddøen som straf for Amleths tvetungethed. Dette er sikkert den oprindelige tankegang, jf. Grundtvigs uvilje mod Sigurd orm-i-øje (str. 127-133, Gr.symb. s. $155 \mathrm{f}$.).

Stroferne 55-63 er altså hermed på indicier kendt indskudt eller omarbejdet på digtets sidste stadium. Hertil svarer også deres stilistiske lighed med det nybrud $i$ ånd og tone der samme år var sket med Prøver af Snorro og Saxo, hvor Grundtvig havde sat en jævn folkelig gemytlighed i hævd, af ham selv kaldet Borgestu-Dansk ${ }^{5}$ ). I str. 55 genoptages de hager Amleth som stor dreng lavede som

4) ○: dus, d.v.s. skjul, dække; $w$ skal jævnlig udlæses $u$, mens $f f(u)$ svarer til $v$. - Forøvrigt er den ellers så latinsikre Grundtvig både her og Saxo I s. 169, ligesom rimkrønikeforfatteren og Vedel, gået $i$ vandet på Saxos underfundige fremstilling, med spil på navnene på tre moseplanter: hestehov (ungulum jumenti), hanekam (crista galli, almindeligt kaldet skjaller), og tagrør (laquearia tecti), jf. Axel Olrik: Kilderne til Sakses Oldhistorie II (1894) s. 160, og Johs. Brøndum-Nielsen: Om Rimkronikens Sprogform og Tilblivelse (1930) s. 61.

5) Jf. senest Skautrup: Det danske sprogs historie III (1953) s. $324 \mathrm{ff}$. 
forberedelse til kuppet, med »skæmtesagens« ord: »... skue ei Hund paa Haar! / Den altid har en Hage«, en af Grundtvigs typiske associative brandere. Videre finder vi der ophavet til det billede Grundtvig siden skulle bruge ved gendigtningen af og efterklangen til Saxos Bjarkemål: de røde emmer ${ }^{6}$ ), brugt som symbol på guld og på krigere, nok endnu holdt $\mathrm{i}$ sin oprindelige betydning, men et vidnesbyrd om iagttagelsesevne parret med fantasi. Linjerne gengives her side om side med Grundtvigs forklarende note om det jyske mundheld:

Det er en Spas som Jyden holder af, Og Skam faae den der stander hos, naar han vil fixere godt Folk, at rage Naar Jyden skifter Arvegods Alt i de røde Emmer.

hede Emmer sammen og slaae deri, saa Gnisterne flyve om godt Folks Øren, og det kalder han at skifte Arvegods.

Ligesom de formentlige eftervirkninger hos Grundtvig er drastiske, hører i den gamle krønike Amleth-afsnittet til de forholdsvis få hvis styrke er en frisk fremstilling hvor råt for usødet hører til dagens orden. Dette gælder nok også - skønt Gr. senere fandt at hele vedkommende rim hørte hjemme i kroen - en af de stumper han ved sit hovedkulds møde med rimkrøniken (jf. ndf.) først stiftede bekendtskab med, den malende skildring af hvordan Starkad afliver Ingels tyske dronning (v. 1211-18), måske en ekstra tilskyndelse til det drastiske billede med mortensgåsen. Stedet citeres her efter Gr.s afskrift (på et særligt kvartlæg i fasc. 288, som der siden skal gøres rede for), med et par typiske sproglige associationer:

Tha Drotninghen saa thet byrthings bad

Tha vor hun ey meghet gladh

Thet gaff Starcather intet gem (guam á)

Men setthæ hennæ under syn belthe rem,

Alth som en hønæ med hoffuet og hals

Saa giordhe (gjordedes) han seg forudhen fals

Han gjordhe segh tha saa meghet indh

Ath hun mysthæ tha baade liff oc syndh.

At stedet i første omgang har tiltalt Grundtvig ved at være anvendt som hjemmel, skal vi komme tilbage til. Foreløbig vil vi fastholde hvad vi allerede har mødt i hans formodede overarbejdelse af Amleth-afsnittet $\mathrm{i}$ rimkrønikens (og Saxos) ånd, den primitive

6) Jf. Grundtvigs symbolverden s. $263 \mathrm{f}$. Hvad billeddannelsen ved emnerne angår, har indtrykket af den levende jyske situation sikkert større betydning end Lyschander-citatet, som William Michelsen henviser til, Tilblivelsen af Grundtvigs historiesyn s. 103. 
realisme, som et typisk træk for folkelitteratur ${ }^{7}$ ), en naiv brutalitet der kun ser sagen fra heltens eller hævnerens synspunkt, uden at tynges af den lidelse der tilføjes ofret, ud fra den enkle moral: han har ikke fortjent bedre. For Grundtvig betyder det en frigørelse af frejdig anskuelighed, noget den unge Oehlenschläger havde taget sig uden forlov, f. eks. da han skildrede stemningen efter dåden i romancen Uffe hin Spage (i Poetiske Skrifter, 1805):

En Herold for Kongens Sæde
Treen, og qvad det muntre Vers:
Een paa langs, og Een paa tvers!
Da græd Gubben høit af Glæde.

I det yngste lag i Et Blad af Jyllands Rimkrønike har vi da ment at konstatere lån eller påvirkning fra den gammeldanske, og denne mulighed må vi også regne med i selve overskriften. Bortset fra det litterære skyldes dette en tydelig historisk tendens, en bevidst drejning fra den teologiske der havde domineret hans forfatterskab i de foregående år. Dette svarer til Grundtvigs egen bedømmelse fra 1824, som først er offentliggjort af Begtrup (US IV s. $229 \mathrm{ff}$.), i det første Christianshavnsbrev ${ }^{8}$ ) i den fiktive Brevveksling mellem Norrejylland og Christianshavn (fasc. 99). Der vil her - mere end de fleste andre steder - være grund til at præcisere at det foretagne udvalg tjener nærværende undersøgelses problemstilling, og fra ethvert andet synspunkt kun vil fremtræde som en ægte helhed ved udfyldning af de her foretagne udeladelser (US IV s. 232 f., 234):

Min anden Periode, til 1815, kalder jeg den theologiske, skiøndt man vel neppe vil regne Noget af, hvad jeg skrev, undtagen mine Prædikener, som endda udkom senere, til Theologien; men jeg kalder den saa, fordi al min Skrift, fra den Tid, dreier sig om enfoldig Troe paa Skriften, som et aabenbart Guds Ord, og den deraf flydende Troe paa Jesum Christum, som det eneste Saligheds-Middel for syndige Mennesker. Om denne Deel af min Bane give mine Skrifter i Grunden al den Oplysning, jeg kan give; thi hvem der, efterat have læst dem, tvivler om, at jeg talede, fordi jeg troede, ham vil min

$\left.{ }^{7}\right)$ Grundtvigs vågnende eller genvågnende sans for sagn ses også $i$ et indgående referat tidligere på det omtalte kvartlæg af traditionen om hundekongen, som han første gang har mødt her i Scriptores.

8) Christianshavnsbrevene, som er de betydeligste, er Grundtvigs svar på imaginære forespørgsler fra Nørrejylland. Femte Christianshavnsbrev er siden trykt blandt tillæggene i Gr. symb. (s. 229-233). Indgående referat af hele værket og fyldige citater findes i Henning Høirup: Grundtvigs Syn paa Tro og Erkendelse (1949) s. 175-226. - Til dels med udgangspunkt i 1 . Christianshavnsbrev, har jeg, ud fra stilistiske kriterier, forsøgt en periodedeling $\mathrm{i}$ afhandlingen Stadier $i$ Grundtvigs forfatterskab (Acta Philologica Scandinavica XIX, 1947-49, s. 143 ff.). 
gientagne Forsikkring vist ikke tilfredstille, og han hører overalt til de Folk, med hvem jeg Intet har at tale.

Min tredie Periode, fra 1815, kalder jeg min historiske, og deri vil man vel være enig med mig, da Alt, hvad jeg siden har skrevet, dreier sig om den Paastand, at det ogsaa i det Store kun er af Erfaring, man bliver klog, og at derfor Historien er Noget, der, saavidt mueligt, skal være Alle bekiendt, at den, som ene omfatter alt Menneskeligt, ogsaa kan og skal forbinde og forklare det.

Her ser De Baandet, der sammenknytter Dannevirke med Bjovulfs Drape, Udsigten over Verdens-Krøniken for lærde Folk med Fordanskningen af Nordens Krøniker for Menig-Mand, og er min Paastand om Historien saa uigendrivelig, som jeg anseer den for, da maa det være let at udfinde Sammenhængen mellem mine sidste Perioder, thi de forholde sig da til hinanden, som Oplysning til Opbyggelse.

Der er hertil at sige at i 1824 havde Gr. faaet rimkrøniken på afstand. Da han ved Molbechs udgave 1825 atter fik den ind på livet, vidnede han $\mathrm{i}$ et af hovedudkastene til anmeldelsen i $\mathrm{Nyt}$ Aftenblad 1826 (forrest i fasc. 288, begyndelsesordene identiske med NAft s. 130 sp. 1 lin. 25-28) om dens betydning for ham under det store oversættelsesarbejde ( $2 \mathrm{r} 2$, rettelser ignoreret):

Dog, kun forgiæves vilde jeg stræbe, i Korthed og dog Skridt for Skridt, at opvise den i een Bog vel mageløse Forskiellighed, der alt ved Rim-Krønikens første Læsning, for ti Aar siden, saa besynderlig slog og underlig bevægede mig, at saa blandet og dog heeligiennem saa dybt et Indtryk har ingen Bog gjort paa mig, hvad man langt bedre kan see i Fordanskningen af Krønikerne, end i Dannevirke; thi i hin Fordanskning er min egen Fordanskning ved Rim-Krøniken uvilkaarlig aftrykt, saa det er intet Under, den seer broget ud, skiøndt jeg tør haabe, den dog skal findes levende, fordi jeg ikke sammenlappede den af hvad jeg kun fandt i Bøger, men sammensmedede den af alt det Danske, jeg, ved at randsage alle mine Lommer, kunde finde hos mig selv.

Når man med dette in mente sammenligner oversættelserne med Grundtvigs principielle bemærkninger til stilforskellene i rimkrøniken, melder der sig et spørgsmål om teori og praksis. Både i dette og andre udkast anker han over den stigende småordsfrekvens i rimkrønikens senere del, og samtidig fremhæver Rubow (Saga og Pastiche, 1923, s. $51 \mathrm{f}$.) de rigelige indskud af småord som typiske for Snorreoversættelsen og overhovedet Grundtvigs senere prosastil. Modsætningen medieres rimeligvis ved at rimkrøniken har lært Grundtvig at give agt på forskellen på poetisk og prosaisk stil; i hvert fald holdt han op at skrive hvad Poul Møller kaldte »Sjapdigte« nogenlunde samtidig med bekendtskabet med rimkrøniken.

Da vi nu har foregrebet omtalen af udkastene fra 1826 , er det fristende at afrunde denne drøftelse af rimkrønikens formentlig ældste spor i Grundtvigs litterære produktion med hans fremhævelse 
(samme udkast, 1v) af Amlethafsnittets enestående værd i krønikens ældste del, så det ene blandt alle rimene henlægges til den Grundtvig så kære borgestue:

uagtet alle Rimene fra Humbles til Harald Olufsons, er af een BygningsMaade, kan de dog umuelig være af een Byg-Mester, med mindre han kun selv med alle sine Svende har bygget Amleths Borge-Stue, og overladt Resten af gamle Leire-Gaard til Prøve-Klude for sine Drenge, thi det er aabenbar, hvad Konsten angaaer Forholdet mellem Amleths Rim og alle de Andre: Det er kun hvad man nu kalder en Borgestue, men saa dramatisk levende - saa vel indrettet og saa morsom en Borgestue, som man i Danmark kan onske sig, medens baade Skjolds og Rolvs og Frode Fredegods Rim kun er at ligne ved røglede Rune-Stene, og Ingels ved en Kæmpe-Kro, hvor det vel gaaer levende og kraftig til, men hvor man dog aabenbar har drukket som de Svin, Amleth nok vil skiænke for, men ei ligge hos.

Når jeg har fundet det forsvarligt at afrunde fremstillingen med disse argumenter fra de fornyede rimkrønikesysler 1826 (evt. december 1825), skønt Grundtvig også efter sin modning foretog betydelige omvurderinger fra det ene tiår til det andet, er det ud fra den formodning at de rummer mere end en baglæns rekonstruktion. Under alle omstændigheder griber rimkrøniken pludseligt og mærkeligt ind i Grundtvigs forfattervirksomhed.

Grundtvigs vej til rimkrøniken har nemlig været mere bugtet end man skulle have ventet. Første gang han mødte den var i spredte citater $\mathbf{i}$ et lærd latinsk arbejde fra begyndelsen af det 16 . århundrede, gråbrodermunken Petrus Olais (Peder Olsens) Collectanea, uddrag og optegnelser fra middelalderlige historiske håndskrifter, originalhåndskrift $\mathrm{AM} 107,8^{\circ}$, Universitetsbiblioteket, optrykt af Langebek i Scriptores rerum Danicarum medii ævi I (1772), som Grundtvig har gennempløjet 1815 eller et af de nærmest foregående år, jf. ndf. Desværre har Langebek, der i almindelighed nyder godt ry som udgiver, ikke behandlet Petrus Olais optegnelser fyldestgørende; han har dels foretaget væsentlige udeladelser, dels prøvet at få noget efter sit udarbejdelsesprincip fragmentarisk til at fremtræde som en helhed. Det første går ud over den danske rimkrønike, hvoraf Petrus Olai til vidt forskellige tider havde noteret sig to afsnit. Det ene er den i rimkrønike-litteraturen meget omtalte danske form af det fortalerim hvormed den nedertyske oversættelse $i$ 1477 var overrakt Christian I; det havde Langebek optrykt 1749 i jubeltalen over denne konge, men udelod det altså i Scriptores. Mens dette adskiller sig fra håndskriftet iøvrigt ved at være skrevet med kursiv og næppe før 1525, hører det andet udeladte parti 
(AM $107,8^{\circ}$ blad $11 \mathrm{r}$ ) til håndskriftets ældste bestanddele. Det er næppe meget yngre end Ghementrykket 1495, som det i tre tilfælde frembyder bedre læsemåder til. I forskningen har det haft en krank skæbne; det er - for eneste gang - nævnt i Molbechs indledning (s. XI f.), men ikke benyttet i hans variantapparat. Stofligt er det noget af det som ved gennemlæsningen af Ghemens tekst fængede Grundtvig mest: det meste af Humbles og hele Dans rim (v. 23-78 og 89-110, forbundet ved en prosaomskrivning af det mellemliggende).

Grundtvigs studium af Petrus Olai, som altså var begrænset til hvad Langebek havde taget med i Scriptores, eller i det hele taget af Scriptores, kan vi delvis følge i udskrifter i fasc. 238, samt et enkelt kvartlæg (4 delvis overrevne blade, mærket dels - som de andre - med I. J. N., dels med et firtal, der, ligesom begyndelse midt $i$ en sætning, viser at det er revet ud af en sammenhæng), som - tilsyneladende tilfældigt - er havnet i fasc. 288, der ellers er opsamlingssted for udskrifter, omdigtninger og fortolkninger af rimkrøniken.

At tilfældigheden mest var tilsyneladende, har omtalen af Petrus Olais rimkrønike-interesser vel allerede røbet; for på det vildfarne kvartlægs sidste sider har Grundtvig afskrevet tre rimkrønikestumper som Petrus Olai havde indføjet $\mathrm{i}$ sin latinske tekst på en måde der afskar fra udeladelse i Scriptores. Det sidste af disse er det tidligere citerede parti om Ingels dronnings ynkelige endeligt, der direkte benyttes som hjemmel. Petrus Olai kender nemlig to traditioner for dronningens endeligt, en der blot ( $i$ overensstemmelse med Saxos vers) advarer Ingel mod hans skændige hustru der kunne blive mor til en lige så slet søn, en anden der på latin omskriver versene om kvælningen under Starkads bælte og så med ordene »Unde chronicon vulgare«: slår over i rimkrøniken. Mens dette i håndskriftet sker uden nogen som helst markering i linjedeling eller skrifttræk, opstiller Langebek dem tydeligt strofisk.

På samme måde forholder det sig med det andet citat: Hjarnes eller - som rimkrøniken og senere også Grundtvig kalder ham Hjærnes ligvers over Frode (v. 1073-78). Sagligt er det dette og det allerede så grundigt omtalte der har betydet mest for Grundtvig. Men filologisk set har vi mest nytte af det første (v. 999-1002), til rimkrønikens teksthistorie fordi antallet af krigere $i$ den anden af de omtalte hære (v. 1000) opgøres til 63.000 i stedet for Ghementrykkets (og det deraf uafhængige Stockholmerhåndskrift $\mathrm{K}$ 41's) 360.000 , til Grundtvigs rimkrønike-benyttelse fordi det klart frem- 
går at han endnu ikke har kendt rimkrøniken i dens helhed, eller dens særkende: jegformen.

Dette kan bevises ud fra den måde Grundtvig i sin optegnelse restituerer v. 1001 på; dettes første halvdel er nemlig hos Petrus Olai omskrevet til latinsk prosa, hvorfor Langebek da også her (Scriptores I s. 85) trykker citatet fortløbende med den øvrige tekst:

Contra hunc venit rex Ungarorum cum classe navium Nisinde tusinde oc tusinde Men trytusinde oc LX. ther til en. Qvos omnes occidit i Østre Strand som løber vthen for Blekings Landh.

I Grundtvigs udskrift bliver den tredje linje (v. 1001) til: 》han slog dem alle ihjel i Østræ Strand«, der vidner om ukendskab til Ghemens form: 》Them slo ieg i den østræ strandh.« At Grundtvig ikke evner en sikker restitution, ses tydeligst af at han sætter Østræ Strand $i$ en linje for sig, efter ovenover at have overstreget Østrestrand.

Denne forbløffende famlen overfor rimkrøniken i 1814 eller 1815 stemmer med Grundtvigs eget vidnesbyrd mange ar senere (Nordisk Kirke-Tidende 1834 sp. 558):

Det klinger pudsig, men det er baade sandt og sørgeligt, ja, det gaaer saavidt, at skiøndt jeg aldrig har kiendt en større Vovehals mellem Bøger end jeg selv er, og skiøndt jeg ikke vidste rettere, end at Sky-Haarene for de Lærdes Ban-Straaler var for længe siden blæst af, saa blev jeg dog over 30 Aar gammel, inden jeg fik Mod til at see med egne Øine, hvad den gamle Danske Rim-Kronike havde syndet, og fandt da at saa puur og pære-dansk en Bog havde jeg aldrig i mine Dage læst, saa »Latinerne« havde ligesaa skiellig Grund til at fordømme, som jeg til at ophøie den.

At Grundtvig var »over 30 Aar gammel«, berettiger os - i hvert fald hvis vi er tilstrækkelig rigoristiske - til at antage at han tidligst er kommet $i$ gang med den på sin 31 års fødselsdag, 8. september 1814, og sandsynligvis lidt senere. Hvor meget senere, har vi indirekte et holdepunkt for, idet han i første hefte af DanneVirke, hvis fortale er underskrevet 19. oktober 1816, bringer det velforberedte udvalg af rimkrøniken vi senere skal komme tilbage til, og hvis filologiske forberedelse synes at stamme fra forsommeren 1816. Mest sandsynligt er det sket i 1815 , da det synes at have sat sig spor, mens Heimdall var i trykken; det er i denne forbindelse ikke uden interesse at Grundtvig til str. 138 af Et Blad af Jyllands Rimkrønike føjer en stor note med udvalg af Ermold Nigellius' latinske vers om Harald klaks dåb i Ingelheim og henvisning til Scriptores I. 
Vi har dog endnu et holdepunkt, i Grundtvigs foredrag 15. juni 1841 , om den folkeudgave hans tro tilhænger Chr. S. Ley samme år havde udsendt. I dette utrykte foredrag (der ligger i fasc. 364, og som Steen Johansen har gjort mig opmærksom på) hedder det (10. side) at »strax efter den bedrøvelige Syvaars-Krig da faldt det mig ind, at den Bog, vore Forfædre havde holdt saa meget af og læst saa flittig i maatte dog vist ogsaa for deres Børn være værd at læse og især ægte Dansk«. Det er da naturligst at antage, at lammelsen ved freden i Kiel har udløst det intense studium af kilderne til Danmarks gamle, glorværdige historie, hvorved Grundtvig halvt uforvarende dumpede ned i rimkrøniken. At den bagvendte introduktion, som skinner igennem i artiklen i NKT, er blevet så godt skjult i foredraget, skyldes det naturlige talerkrav om hellere at understrege end at redegøre.

Da Grundtvig først var blevet opmærksom på rimkrøniken, kastede han sig lige ud i studiet af den, som vi kan se af et dobbeltblad i kvartformat i fasc. 288 (vandmærke CEIH, desværre det almindeligste af dem alle, afmærket i.i.n., kun bindestreg i ét eneste ord: Middel-Alderen). Tekstbestemmelse ud fra indholdet viser at det er en endnu umoden forløber for indledningen til Danne-Virkeudvalget (DV I s. 35-39), som sagligt er anderledes funderet. Når det alligevel aftrykkes, er det for at vise hvor hovedkulds Grundtvig var kommet ind i rimkrønikestudiet, et træk der allerede røber sig ved to mærkelige bemærkninger over overskriften: »Udentvivl er det den bedste《 og »Fremdeles«. Det må bemærkes at teksten er et fragment, som næppe har været fortsat (hvor Gr. mod sædvane er kommet til at sætte punktum uden at sidste sætning er afsluttet, og bagefter har tilføjet de sidste ord, så »og mig《 står alene i fjerde sides nederste linje), og at kun et par rettelser med saglig betydning er markeret.

\section{Om den danske Rimkronike}

Saavidt jeg veed er Riimkrøniken noget aldeles Nordisk og Man kan vel sige Dansk, thi neppe findes der udenfor Norden noget Folk der fra MiddelAlderen har en saadan fortløbende rimet historisk Fortælling om sine Fyrster og mærkelige Hændelser, og er den giennemløbende svenske Riimkrønike, ikke hvad den synes at være, et Fuskerværk fra midt $i^{9}$ ) det 16tende Aarhundrede, saa er den dog altid nogle hundrede aldeles ubetydelige Riim, der ikke have mindste enten poetisk eller historisk Værd, med mindre Man kan troe og finde Smag i Riim som dette om en Urbar Frodason:

9) Ordene »midt i« indsat senere. 
Jagh bodde i Göthariike ${ }^{10}$ ) medh roo

Til thes jag i Upsala doo,

Mina tree Söner fik jak min Land

Dan fik jak Vetalahedh i han

Min Möderne-Land fik jagh Nöre

Och Østin stander Gothana före,

Israels Konung David Propheta

Var i min tiidh hoo thet vil vita.

At her er overfledig Indhold kan ingen nægte men om dens Værd er det vel ligesaa overflødigt at tale, som om Skiønheden, og skiønnere er dog neppe noget af de andre Vers, som for det meste kun sige: jeg var Konge i Sverrig og døde. Vel have de Svenske endnu noget Andet som de kalde den gamle vidtløftige Riimkrønike, og er virkelig et baade vidtløftigt og kiedsommeligt Rimerie om svenske Handeler fra Erik Læspe (1223) til Steen Sture, den er ingenlunde unyttig for Historikeren, har meget mere for ham allerede stor Mærkværdighed som det ældste svenske Riim Man kiender, men selv Udgiveren Hadorph finder den gruelig upoetisk og Vers som dette:

\section{Pund Kött, 2 Pund Flæsk, 2 Pund Fisk 2 Pund Smør Hvar Gaard hon saa mycket uthgör}

henpege paa den begribelige og reelle Smag der hersker i det Hele. De eneste svenske Stykker der da skulle kunne sammenlignes med den danske Riimkrønike er nogle faa Vers i Hadorphs Fortale, og Tillægget til det lange Riim, som handler om Kong Hans og Christian den Anden, thi her fremføres Kongerne selv talende, og Man finder virkelig Spor af den muntre, naive Livlighed, der $\mathrm{i}$ den danske Riimkrønike er et saa tiltrækkende Hovedtræk, men Man finder ogsaa aabenbare Spor af Efterligning, for ikke at sige Plagiat, som Man vel maae kalde de Linier i Fortalen:

Svenske ære kompne aff en goder Mand

Noæ Sön Japhet saa heet han,

Yngste Noæ Søn og tridie han var

Och skylte sin Fader nær han lagh baar

Therföre bleff han vælsignet igen,

Med sin Broder og Gudz trogne væn

Nær Noe vælsignade honom med Gudh,

Och badh honom vidgas om Verlden uth,

Och Cham hans broder badh vara hans svæn

Som han hafver varit og ær nu æn,

Thenne vælsignalse alla Svenske Mæn ærfde

Som Japhet theras Fader them førværfde

Henne at behaalla uthan ænde

Gudh ther til sina naader sænde!

10) Grundtvig gør sig øjensynlig umage for at skrive et tydeligt svensk ö, men glemmer det undertiden. Dette er et bevis for at hans danske $ø$, der tit minder om ö, skal udlæses ø; (stort) $\varnothing$ og æ skriver han også i det svenske. 
Hermed sammenligne Man Begyndelsen af den danske Rimkrønike hvor det hedder:

Jeg Humble vil ey haffuet forgeth

Ath Danskæ komme først aff Japhet

Som Noes søn then tredie var

Han skjulde syn fadher tha han laa bar

Therfore han velsyneth bleff

med Sem syn brodher gild oc geff

Tha Noe velsynæde hanum medh Gud

och bad hanum vides om landhen ud

Oc Cam hans brodher bad være hans svend

som han haffuer værit og ær oc end

Then velsygnelsæ haffue danskæ men ærft

Som Japhet ther' fadher fik them forverft

The henne beholde til evig tiid

thy mun the leffue for uthen qvijd.

At den ene har stjaalet er aabenbart og den der er blind for indvortes Grunde, kan dog see, at den danske Riimkrønike er trykt 1495 og dette svenske Fortaleriim ikke engang i Messenii Udgave, men først i Hadorphs 1674, og hvad da saa end Tyven heed seer Man vel hvor han stikker.

Dog, uden at gaae videre heri dennesinde og forbigaaende de tydske Vers ved Fyrsternes Contrafeyer i Saxen som ${ }^{11}$ ) kun synes at ligne lidt hvad Talen er om, vil jeg begive mig til den danske Rimkrønike hvorom det var min Agt at tale og paaminde. Hvorvidt der af denne mærkelige Bog gives Afskrifter xldre end dens første Trykkeaar 1495. er mig ubekiendt, og mig

Det er bemærkelsesværdigt at hele Grundtvigs udredning er saglig, ikke sproglig, idet det først var i forsommeren 1816 han foretog det filologiske rimkrønikestudium der er forudsætning for offentliggørelsen i Danne-Virke I. I artiklen Om Ordsprog siger han selv (DV III s. 84, US III s. 504) at det var »saare godt, at jeg fik Tid at summe mig, Tid f. Ex. til, i Fjor tilbunds, saavidt jeg kunde, at undersøge Riim-Krøniken, og gamle Laales Ordsprog, og Vocabulariet ad usum Dacorum fra 1510, hvoraf jeg lærde mere Dansk, end der i alle vor Tids Bøger er at finde«. De to sidstnævnte afskrifter, der er bevaret i Grundsvigarkivet fascc. 291 og 299, Peder Laales ordsprog og Christiern Pedersens Vocabularium omstillet efter danske opslagsord, stammer fra maj og juni 1816 (jf. min bog Grundtvig som filolog (1946) s. 59), mens rimkrønikeudskriften rimeligvis er de kortere og længere afsnit med understregede kerneord som blandt meget andet findes i fasc. 288 , men jo har et helt andet sigte og forudsætter langt større fortrolighed med rimkrøniken end det ovenfor gengivne. Dette hører altså til et ældre lag end sprogstudiet i forsommeren 1816.

11) Herefter udstreget: i Formen. 
Hvis dateringen af denne foreløbige redegørelse for den danske rimkrønike, helt til eget brug, holder stik, er det ikke urimeligt at Grundtvig for anden gang i samme år har ment at skulle til at gøre nationallitterært pionerarbejde; han havde jo om sommeren vakt furore ved at udkaste den dybe danske udlægning af Beowulf, og synes allerede her i sit ufuldkomne rids at have anet store perspektiver for rimkrønikens tolkning $\mathrm{i}$ en lignende ånd. Mange enkeltheder - f.eks. at rimkrøniker skulle være enestående for Norden - tvang videregående studier ham siden til at revidere; men kernen, og at der forelå en svensk-dansk polemik, havde han set rigtigt i. Hvor meget kendskab han i forvejen havde til svenske rimkrøniker, er ikke let at afgøre. Han henviser direkte til Messenius' og Hadorphs udgaver; men det siger intet om hvor tidlig han har beskæftiget sig med dem. Det eneste holdepunkt frembyder en liste over store navne i de foregående århundreders svenske åndshistorie, samlet på et enkeltblad i fasc. $209^{12}$ ), der desværre er vanskeligt at datere ud fra ydre kriterier, men dog snarest minder om daterbare optegnelser fra omkring 1808, da Grundtvig påbegyndte sin virksomhed som historielærer i det Schouboeske institut. Næsten alle er udstyret med en biografisk notits og/eller en henvisning til et værk. Navnelisten, hvori er indskudt en parentes med henvisning til Acta litteraria Sveciæ (1723-29) og R. v. d. Hardts Holmia literata, lyder: Rudbeck - Peringer (o: Peringskiöld) - Laurentius Petri - Messenius - Loccenius - Stiernhielm - Verelius - Lagerbring - Dalin - Linné.

Mens den sidste måske er kommet med for sin nære tilknytning til den første (kommentaren lyder blot: »fra Smaaland en Præstesøn som de forrige, 1707«), anes der en klar sammenhæng i de øvrige: Det er alle dem der har arbejdet på at skaffe Sverige en glorværdig oldhistorie; flere af dem vides at have ejet svenske rimkrønikehåndskrifter, og Messenius hører jo endda til udgiverne. For danske er Rudbeck det kendteste navn, som huskes fra Holbergs epistel 193 om hans hovedværk Atlantica. Denne epistels yndest skyldes nok mest Holbergs kåde spot med de hasarderede etymologier som bevis for folkefastemning - Nestor som grundlægger af Næstved, Jylland afledt af Juda osv. og, som supplement til disse snilde påfund, det ægte citat fra en nedertysk forfatter, hvor Dacia Ripensis (Dacien ved Donaubredden, dvs. Rumænien) udlægges som »Ripen in Dannemarck«; dette citat, af en anonym,

12) Det bør dog tilføjes, at der sammesteds ligger lister over danske, holstenske og rigstyske personligheder. 
håndskreven krønike, var benyttet i Peringskiölds noter til hans udgave af Johannes Cochlæus: Vita Theoderici regis Ostrogothorum, 1699 (jf. Billeskov Jansens note, Epistler VII (1953) s. 23). - Med moderne historiske begreber er satirens genstand uendelig fjern, og vi glemmer rent at de lærdes etymologiske fantasterier greb så stærkt ind i det historiske studium at påtale var fuldt så påkrævet som angrebet på de akademiske formalia i Erasmus Montanus; i en yngre alder ville Holberg rimeligvis have gjort det til genstand for en komedie. Men ligesom løjtnantens store tale om den sande videnskabelighed afslutter Erasmus Montanus, således er ep. 193 ufuldkommen uden ep. 194, hvor Holberg drøfter den nordiske oldgranskning for ramme alvor og i stedet ønsker bedre plads til moralstudiet. Afsnittet mod det nationale fantasteri lyder:

Jeg fordømmer dog ikke dem der legge Vind paa Fæderne-Landets Antiqviteter, men dem, alleene, der fordybe sig saaledes derudi, at de tilside sette alle andre nyttige Studia; og dem, der med lukte $\varnothing_{j e n}$ see, hvad andre ikke kand see med Perspectiver. Man kand ligne dem ved Febricitanter og visse tungsindede Mennesker, som udi Norge kaldes Fremsynede, efterdi de overalt see Dødninger og Spøgelser, som andre aldrig blive vaer. Det er saadanne alleene, som jeg i ommelte Brev haver skiemtet med, og ikke med Antiqvariis udi Almindelighed. Thi jeg læser selv alle gode gamle Bøger, og er ligesaa stor Elsker af rimelige Antiqviteter, som jeg er Hader af u-rimelige Fabler. Alt hvad jeg derved erindrer, er, at mange af vore Nordiske Lærde giøre formeget deraf, saa at nyttigere Studia og Hoved-Pligte derved sættes tilside. Jeg bytter gierne en Rudbeck, en Lyschander, en Strelov, en Petreium, og fleere saadanne Bøger bort for en eeneste Arent Berentsen, og setter meere Priis paa et af de mindste Stykker, som af det nu blomstrende Videnskabers Societet udi Sverrig kommer for Lyset, end paa alt det Liggendefæx, som Johannes Magnus og Olaus Magnus have efterladt sig: Og vilde jeg ønske, at alle Studeringers Patroner vare ligeledes sindede; saa at der blev arbejdet paa at indskrænke visse Studia, og forfremme andre.

Så megen energi ville Holberg ikke have sat ind på at mane spøgelset ned i jorden hvis det ikke havde været fordi det forfærdede ham. Arent Berntsens Danmarckis og Norgis fructbar Herlighed (1656), tvillingrigets topografi med dens mangfoldighed af kulturhistoriske og statistiske oplysninger, vendte han atter og atter tilbage til, og det naturvidenskabeligt betonede Kungliga svenska Vetenskapsakademiens »Handlingar《 slugte han; men han gjorde altså skarp front mod den fantastiske historieskrivning med dens stamfaderudredninger, og fandt det påkrævet at gøre det!

Det er dette sidste der er det vigtigste, fordi Holberg aldrig kæmpede med vejrmøller. Med sin sans for det aktuelle rettede han imidlertid kun sin brod mod de nyere eksempler på denne litteratur, i Danmark Lyschander, i Sverige Rudbeck og forud for ham Olaus 
Magnus' udgave af sin afdøde broders Historia de omnibus Gothorum Sueonumque regibus, uden interesse for at disse værker fortsatte en middelalderlig svensk-dansk polemik om hvilket af folkene der i kraft af afstamning fra Jafet var det ældste og dermed det kvalificerede herrefolk. De svenske og danske litteraturhistorikere har haft svært ved at komme helt til bunds i denne strid om oldhistorien, og ingen af dem har haft blik for dens forudsætninger i europæisk litteratur.

Allerede i oldtiden regnedes det for et stort aktiv for et folk at kunne påberåbe sig nedstamning fra Herkules eller en anden navnkundig helt; og efterhånden blev det almindeligt at nedregne sin æt fra de undvegne trojanere. Det berømteste eksempel er Vergils Eneide, hvor vi også finder den typiske etymologiske byopnævner, Romulus; hos andre forfattere hedder det på samme måde at Ninive er grundlagt af Ninus. Disse etymologiske folke- eller byopnævnere følger tæt på hinanden op gennem århundrederne. Ved sin død efterlod således Ronsard en ufuldendt Franciade, og en så rationel ånd som Newton brugte sine sidste år til spekulationer over antik kronologi, baseret på en forestilling om ens længde for alle generationer. Det er en broget litteratur, som aldrig er gjort til genstand for en samlet fremstilling, skønt mange af dens enkeltheder er vel oplyste; som en af de bedste blandt monografierne skal her blot nævnes Hans Matter: Englische Gründungssagen von Geoffrey of Monmouth bis zur Renaissance (Anglistische Forschungen 58, 1922).

I første omgang tog den katolske kirke ikke anstød af disse teorier om trojansk afstamning; $i$ den store kronologiske tavle som stammer fra kirkefaderen Eusebius, indsættes de trojanske stamfædre parallelt med de bibelsk afhjemlede rækker af Sems afkom. Men efterhånden finder denne $i$ kristenheden en konkurrerende lære: at folke- eller fyrstestamfædrene nedstammer fra Jafet. Dette sker første gang hos den jødiskfødte, latinskrivende historiker Josephus i 1. århundrede e. Kr., men i den skikkelse der trængte ud i de europæiske litteraturer, i den anonyme, græsksprogede Diamerismos tes Ges, bogen om jordens fordeling, som er indgående beskrevet i Alfred v. Gutschmids posthume Kleine Schriften (V, 1894, s. 585-717 og 240-273), og siden af Adolf Bauer identificeret som Die Chronik des Hippolytos (Texte und Untersuchungen zur Geschichte der altchristlichen Literatur, NF. XIV Hft. I, 1905). Dette system, der udbyggedes af en række middelalderlige forfattere med populariserende tendens, først og fremmest Isidorus af Sevilla, som Petrus Olai direkte henviser til, hviler på Folketavlen i 1. Mosebogs 12. kap.; en indlemmelse heri var naturligvis en tilfredsstillelse for 
folkene, fordi de derved som beslægtede fik lod og del i Bibelens tradition og forjættelser.

Her i Norden var det skæbnesvangert, at denne lære skulle blive kendt netop under Unionstidens rivalisering. For vel var Danmark politisk førende, men Sverige stod stærkest kulturelt eller i hvert fald litterært, hvilket dog hverken positivt eller negativt kan bevise noget om, hvem af de to der først fik kik på Jafettraditionen og dens politisk-nationale betydning. En fornemmelse af rivalitetens styrke giver et epigram hos Petrus Olai (Scriptores I s. 73, noteret på samme papir i fasc. 288 som de første stumper af rimkrøniken, Grundtvig stiftede bekendtskab med) om danerfolkets navnehæder (udhævningen i sidste linje skyldes dog Grundtvig):

Gothi sunt Dani, Dani Gothique vocati

Hos annis genuit hæc Scythica Dania sævos

Traditio veterum simul et Scythas vocat illos

Nomine sic trino gens Danica glorificatur.

Vi er her midt inde $\mathrm{i}$ den middelaldertradition som vi ovenfor så Holberg satirisere over et nedertysk eksempel på. I samme moderne skrift hvor der er gjort opmærksom på, at navneformerne Dania og Dacia i middelalderen omtrent benyttedes i flæng, siger N. Lukman (Ermanaric hos Jordanes og Saxo, Studier fra Sprogog Oldtidsforskning nr. 208, 1949, s. 16):

Man kaldte altsaa de nordiske Folk og Lande med Romernes Navne for Donauprovinserne Noricum, Dacia og Scythia. Det var de Egne, hvor Goterne havde boet i 4 . Aarhundrede ${ }^{13}$ ).

13) Når hertil føjes (også fra Lukman) at $\mathrm{i}$ angelsaksisk tradition var goternes hjem nær Wislelond (Weichselområdet), og at reiðgoternes kamp mod Attilas folk er lokaliseret til »umb Wistla wudu«, spørger man sig selv om der ikke skulle være sammenhæng mellem dette og det mærkelige navn som i middelalderlig gengivelse af nordiske oldsagn tillægges øgruppen Sjælland-Lolland-Falster-Møn: Videslet (i rimkrøniken v. 58 stavet widesleth) eller Videslev; i de svenske tekster, ældst den såkaldte Prosaiska krönikan, der antages at være fra 1453, og er forlæg for Lilla rimkrönikan, hvorfra Grundtvigs citat om Urbar Frodason stammer, regnes Fyn med til gruppen, og den hedder wetala(de) heedh. Det udkastes foreløbig som en sandsynlig formodning at disse rent litterære, forvanskede navneformer udgår fra et udtryk i Jordanes' gotekrønike, som Prosaiska krönikan $\mathrm{i}$ anden sammenhæng henviser til. Ifølge Getica XVII. 94-96 er goterne under kong Berich brudt op fra deres hjemstavn øen Scandza, mens de underlegne, misundelige gepider er ladt tilbage på en $\emptyset$, omgivet af weichselmundingens vadesteder, in insulam Visclae amnis vadibus circumactam. Ved syssel med et håndskrift hvor amnis er faldet ud, kan Visclae vadibus (eller vadis, som også optræder) meget let have 
Man vil måske efter denne udredning indvende at vi er kommet langt bort fra Grundtvig og hans rimkrønikesysler. På en sådan indvending vil jeg svare, at når vi står overfor et moment der har grebet afgørende ind $i$ hans nationale historiesyn, er det lige vigtigt at vi klargør os dets forudsætninger, og at vi har midler til at vurdere det. Det sidste ville vi savne hvis vi ikke kendte noget til de spinkle konstruktioner hos ældre forfattere der lå bag.

Hier irrt sich Goethe! Her er Grundtvig på gyngende grund! Ja, det er han, og det skal siges, for det bliver han ikke ringere af, og vi får en tiltrængt påmindelse om at han ikke, videnskabeligt set, har ret $i$ alt hvad han har sagt, men at han har haft nogle eminente syner og en enestående modtagelighed for hvad der kunne fremme disse; og dem er der grund til at prise ham for, for de har givet ham ret på en anden måde, $i$ digtningens og den skabende fantasis verden.

Vi skal derfor midlertidig se bort fra hvad han ellers fik ud af rimkrøniken - og dèr er der et enkelt punkt hvor det er på høje tid at han videnskabeligt bliver rehabiliteret overfor historikerne - og alene forfølge perspektivet med danskerne som Jafets efterkommere. Kun må vi forinden fremhæve at Grundtvig virkelig har ret $i$ at tilkende den danske rimkrønike prioritet for den indledning han havde fundet i Hadorphs udgave af Twå gambla Swenske RijmKrönikor (1674), hvor den angives at stamme fra den såkaldte Codex Bureanus. Dette håndskrift er fra begyndelsen af det 17. århundrede; det ældste kendte svenske med Jafetperspektiv er hs. Benzelius LI på Linköping stiftsbibliotek fra 1520erne, altså en menneskealder yngre end Ghemens udgave; det er aftrykt Svenska medeltidens rim-krönikor I (1865) s. $193 \mathrm{ff}$.

I Roskilde-Riim havde Grundtvig selv indført en forjættelse til det danske folk: at det hellige vand der er spået om Ez. 47.8, som skulle gå ud gennem Galilæa (»Galilæas Bæk« kalder Gr. det) til havet og læge vandene, er trængt helt frem til og ind gennem Isefjord til rosenkilden (Roskilde) og har helliget den, så den er blevet døbt (jf. Grundtvigs symbolverden s. 200). Og i Europa, Frankrig og Napoleon (s. $96 \mathrm{f}$.) havde han udnyttet et værk der supplerede hans barndoms kære Lyschander, Samuel Bocharts hellige geografi, Phaleg, hvor Dodanim, en af Jafetætterne, identificeres med danerne (danskerne?), og ved hasarderede etymologier sat danskerne og

forledt en nordisk afskriver eller læser til at skabe et navn som kunne få sproglig hævd i hans hjemland. 
briterne i forgrunden, mens nordmændene og ganske særlig svenskerne sås i danskernes kølvand, jf. udførligere referat Gr. symb. s. 304, hvor jeg dog ikke har været opmærksom på at de manglende spor af forjættelsen til danskerne i Humbles rim var sikkert vidnesbyrd om at Grundtvig endnu ikke havde stiftet bekendskab med den.

Men ak! De fire vers i rimkrøniken som var Grundtvig kærest, brød hans jævnaldrende rimkrønikeudgiver, den tabte ungdomsven Molbech, staven over som et uægte indskud og satte parentes om (Ghemen v. 33-36), lige modsat Grundtvig der i sit udvalg (DV I s. 39) havde udhævet de to af dem:

Den Velsignelse have danske Mænd $æ r v t^{14}$ )

Som Japhet der' Fader fik dem forhvervt,

De hende beholde til evig Tid,

Thi mue de leve foruden Qvid.

Når man tænker på hvad denne tankegang betød for Grundtvig, må man prise hans takt $i$ anmeldelsen 1826 at han ikke berørte den drilske parentes, for der er næppe tvivl om at Molbechs uvilje mod disse vers skyldtes at han betragtede dem som nonsens der havde befordret en usund overtro, nemlig Grundtvigs ord i fortalen til Nyaars-Morgen om Danmark som »Historiens Palæstina《 (s. XIX, US IV s. 246). Til vort formål er det imidlertid vigtigere at Grundtvig fastholdt denne begejstrede tro på forjættelsen $i$ alle faser af sin rimkrønikesyssel - fra det første møde med rimkrøniken, rimeligvis i 1815, over to udkast fra omkring 1826 (jf. henholdsvis Gr. symb. s. 305 og PS V s. 391, samt materialet ndf. fra Gr.s omdigtninger af krøniken) til en sidste form Nordisk Kirke-Tidende 1834 sp. 570:

Velsignelsen hun er alle Mands Tarv,
Og ganger hos Dannemænd i Arv,
De hende beholde til evig Tid
Og leve tilsammen foruden Nid!

Hertil må dog lige føjes, foruden den mindre ting at ganger $\mathrm{i}$ renskriften, Collin 219, $4^{\circ}{ }^{15}$ ) (kgl. bibl.), er rettet fra gik, at der fin-

14) I noter forklarer Gr. ærvt (arvet) og mue (mægte, formaae - med henvisning til den etymologiske parallel Formue); henne (rimkrønikens historisk rigtige form) er af mig rettet til hende. - Brøndum-Nielsen støtter (Om Rimkrønikens Sprogform og Tilblivelse s. 53) Molbechs opfattelse p.g.a. versenes ortografiske afvigelser fra de omstående; men da de findes uden sådanne i Petrus Olais afskrift, kan de næppe frakendes ægthed.

15) Jeg benytter herved lejligheden til at berigtige fejlen Gr. s. fil. s. 125 , hvor dette håndskrift er nævnt blandt materialet fra 1826. 
des et samtidigt udkast i fasc. 288 (altså fra 1834), hvor al tale om velsignelsen er strøget og Humbles rim i det hele stærkt afkortet, så vi springer lige ind $\mathbf{i}$ at han var høvding over det mærkelige øvrige Videslet (rimeligvis et lærd fantasifoster, jf. note 13):

Jeg Humle vil ei have forgiæt
Jeg var en Høvding i Videslet,
Saa kaldtes Sælland fra første Færd
Og Smaaland alle saa meget nær
Som groe og grønnes i Øster-Sø'n
Med Lolland, Falster og høie Mø'n.

Derefter følger rimkrønikens beretning om Jyllands befrielse for tyskerne og Dans kongenavn.

At Grundtvig ved trykningen har truffet sit valg for fastholdelsen af den jafetiske arv, ser jeg som et tegn på at 1832 nok rokker ved det nære samhør mellem det nationale og det kristelige, men ikke betyder noget brud med den sammensmeltning af de to som fuldbyrdedes 1815 . Snarest ser det ud som en vipning så det nationale træder skarpere frem end det kristelige, jf. at Grundtvig NKT 1834 sp. 549 kalder rimkrøniken »denne min Liv-Bog, som jeg, ærlig talt, har læst meget tiere og kan meget bedre end min Bibel«; i næste spalte oplyses at han har læst den over 200 gange.

Grundtvigs øvrige kritik af de svenske rimkrøniker kræver et par orienterende oplysninger. Som de forelå udgivet af Messenius og Hadorph, fremtrådte den store krønikemasse, der i G. E. Klemmings udgave (Svenska medeltidens rim-krönikor I-III, 1865-68), i overensstemmelse med de xldste og bedste håndskrifter, deles i Erikskrönikan, Karlskrönikan og Sturekrönikorna, som en enhed, Stora rimkrönikan, der dog ender med Sturekrönikornas 3. afsnit (Klemmings udg. III s. 144, v. 4198); og det er værd at nævne at de 2 pund kød etc. Grundtvig raillerer over stammer fra sidste dels slutning (v. 4179-80), der ikke er oplivende. Men en rolig læsning af længere afsnit af Erikskrönikan - læst med sympati uanset at den tager parti mod kong Birger og hans ildelidte, danskfødte dronning - måtte dog have gjort et andet indtryk, om ikke ligefrem magtstjålet den filologisk årvågne Grundtvig, som det værk fra det 14. århundredes første halvdel den er. Det eneste der har tiltalt ham er tillægget hos Hadorph (ligesom Jafet-indledningen fra Codex Bureanus), fordi det indførte kongerne talende, rigtignok et plagiat af den danske rimkrønike, men dog $i$ dens ånd.

Lilla rimkrönikan er nu som før navnet på den korte svenske 
krønike hvor kongerne beskriver sig selv i ganske korte rim, som både Grundtvigs citat (Urbar Frodasons rim) og karakteristik belyser godt. I modsætning til Erikskrönikan og Karlskrönikan, der mere end nogensinde er i forskningens brændpunkt, er den i det 20. århundrede næsten gledet ud af diskussionen. Den huskes egentlig kun som (det formodede) forbillede for den danske. Lilla rimkrönikan er nemlig digtet mellem 1453 og 1457, med benyttelse af den temmelig tørre Prosaiska krönikan fra 1453, trykt i Småstycken på forn svenska (ved Klemming, 1868-81, s. $217 \mathrm{ff}$.). Mest vægt lægger man i Sverige på at jeg-formen må være opfundet af Lilla rimkrönikans forfatter og derfra lånt til den danske, som næsten alle forskere har været enige om at datere kort før 1477 da Christian 1 fik den nedertyske oversættelse overrakt.

$\mathrm{Da}$ jeg håber ved lejlighed at fremlægge en større redegørelse for den danske rimkrønikes litterære og historiske stilling, skal jeg her nøjes med et nødtøftigt overblik over forskningssituationen, og begynde med at henvise til Johs. Brøndum-Nielsens universitetsfestskrift Om Rimkrønikens Sprogform og Tilblivelse (1930), med en vigtig forskningshistorisk oversigt (s. $26 \mathrm{ff}$.), der begynder med en bedømmelse af Grundtvigs synspunkter, som vi skal komme tilbage til senere; allerede her skal det dog bemærkes at BrøndumNielsen i sit værk hælder til den anskuelse Grundtvig hidtil havde været ene om: at rimkrøniken har mere end én forfatter. - Med Lilla rimkrönikan, som Grundtvig aldrig har befattet sig med på tryk, som den ældste af de to har alle forskere på tre nær affundet sig; af de tre, C. Rosenberg, Verner Dahlerup og svenskeren Erik Neuman, bygger kun Dahlerup på forsvarlige præmisser. Men en helt ny situation er opstået med en endnu utrykt afhandling af Anker Teilgård Laugesen: Til den danske Rimkrønikes datering, som bl. a. viser at det må være den Erik af Pommern sigter til i sit brev ${ }^{25 / 7} 1439$ til Danmarks rigsråd. Det indebærer jo dog at den er ældre end den svenske.

Efter dette indblik i Grundtvigs forberedende studium skal vi følge hans videre faglige indsats med rimkrøniken op. Der er mere lærdom end eftertiden har forstået i det forord og navnlig det efterord hvormed han ledsager de udvalgte rim i Danne-Virke I (s. 35-39 og 204-208); og de vidner om et betydeligt studium i den forholdsvis korte tid han har kendt rimkrøniken. Han har således sat sig grundigt ind i den bevarede afskrift (i GkS 820, $2^{\circ}$ på det kgl. bibliotek) af den i slaget ved Hemmingstedt tabte originale nedertyske oversættelse af rimkrøniken som Christian 1 havde fået foræret, og erkendt at den ikke kunne være oversat efter de kendte trykte ud- 
gaver. Senere skulle C. J. Brandt på sin studierejse i 1851 finde et »missing link« i Stockholmerfragmentet K 41, der er nærmere beslægtet med den nedertyske oversættelse!

Og så har han i efterordet til sit udvalg givet et hidtil uudnyttet fingerpeg til rimkrønikens stilling til annalerne, nemlig det forslag at rimkrøniken skulle være kilde til oplysninger i de latinske annaler - ikke bare de danske citater han var snublet over hos Petrus Olai men dele af den latinske fremstilling (DV I s. 207 f.):

...i den Chronicon Danicum som slutter med 1286 (Script. T. v. p. 329) og agtes af Suhm for omtrent samtidig, findes om Erik Glipping følgende Ord: Ericus filius Christophori Regis successit patri in regno. Hic decimas eclesiarum tulit, nullam fecit justitiam, monasteria ${ }^{16}$ ) per eqvos suos et canes depauperavit, totusqe lubricus uxores nobilium violavit, hvilket for mine Øine at see er omtrent en ordret Oversættelse af hvad vi om samme Konge læse i Riimkrøniken:
Da jeg fik Dannemarks Rige boldt, Jeg ingen Mand Retviished holdt,
Disvær, at jeg saa turde,
Kirken tog jeg sin Tiende fraa;
Med Folk, Heste, Hunde ogsaa
Jeg Klostre fattige gjorde.
Ukysk jeg i mit Levnet var,
Et hadeligt Rygte jeg derfor bar,
Og mest med gode Mænds Kvinne.

At man $i$ en bagvendt Tid, da Konst som Lærdom er Lapperie, kunde faae Lyst til at vende det om og sige, at Rimeren, som naturligviis sammenlappede sin Krønike af Annalerne, har oversat bemeldte Stump, det bekymrer mig ligesaa naturligviis ikke, da jeg skriver for oplyste Folk i et philosophisk Aarhundrede ${ }^{17}$ ). At endelig Rimkrøniken, som mindst $\mathrm{i}$ Begyndelsen af det 16tende Aarhundrede, er agtet for en historisk Kilde fra Middelalderen, beviser ikke allene Petri Olai Chronicon, hvor hele Vers og Linier af den hyppig indføres paa Dansk, men endnu mere Incerti Auctoris Chronicon ab anno 1268 ad 1523 men egenlig kun til 1500, (Script. T. VI.) hvor den udtrykkelig citeres under Navn af Chronicon vulgare og Chronica vulgaris $\mathrm{p}$. 225 og 234. Ved første Sted anmærker Suhm at den Krønike kiender han ikke, men at det i saa Fald kun var fordi han ikke kiendte Riimkrøniken, kan man overbevise sig om ved nøiere Eftersyn.

At der er forbindelse mellem sidstnævnte krønike og Petrus Olais, havde Suhm allerede opdaget; men Grundtvig har ret $\mathrm{i}$ at

18) Trykfejl: mouasteria; derimod er totusque ikke rettet, fordi det er Gr.s opløsning af forkortet -que.

17) En foregående afhandling (DV I s. 107-130, US III s. 326-38) hedder Om det philosophiske Aarhundrede; den er kort karakteriseret af Michelsen (Tilblivelsen etc. s. 195 med note 6) som et udtryk for Gr.s sunde skepsis. 
anholde ham fordi han ikke gennemskuede hvad det var for en krønike på modermålet (chronicon vulgare) der var tale om. Da Grundtvigs synspunkt var så temmelig gemt af vejen, og vel også fordi videnskabsmændene var betænkelige ved hans nationale fantasi, er det ikke ham men Suhm der har bestemt de senere historikeres standpunkttagen, således endnu Kr. Erslev og Ellen Jørgen$\operatorname{sen}^{18}$ ), der regner med en tabt krønike på modersmålet som mellemled mellem de latinske og de yngre: foruden rimkrøniken Chr. Pedersens (der først blev udgivet af C. J. Brandt i 5. bd. af hans samlede skrifter) og en nedertysk (fra ca. 1500) der slutter med Christian 1.s død, Denesche Chroneke; som yderligere argument herfor bruges den derved fuldbyrdede parallel med Lilla rimkrönikan, som var udskrevet af Prosaiska krönikan. - At Grundtvig kan få ret overfor et par forskere af sådant format, skyldes foruden hans sunde instinkt den filologiske træning med latinen, som han selv forkætrede!

Allerede inden Molbechs udgave for alvor satte Grundtvig i gang med rimkrøniken, havde en antagelig bunke papirer med tilknytning til emnet ophobet sig på hans skrivebord. Selv forstod han fuldt vel at dele dem i danefæ og hittegods. Under den sidste overskrift havde han i Danne-Virke IV (s. 174-87) kommenteret et nyfundet ark af et andet rimkrøniketryk end det kendte fra 1495 . Grundtvigs påstand at det skulle stamme fra 1478-80, en tid da Christian 1 endnu levede ${ }^{19}$ ), var vel for ilter; men han havde set rigtigt $i$ at det var en vigtig variant.

Bortset fra Grundtvigs selvstændige nydigtninger, som senere skal behandles, et blad med Svend Grundtvigs notater af »N. F. S. Grundtvigs tilskrevne bemærkninger $i$ et eksemplar af Molbechs udg. af Gl. dansk Rimkrønike«, og de allerede omtalte papirer fra Grundtvigs hånd, rummer fasc. 288: 1) elleve udkast til afhandlingen 1826 ; 2) det $i$ sidste øjeblik udskudte rim om Christian 1, der skulle have stået Danne-Virke I s. 204, for at vise kvalitetsnedgangen i forhold til de foregående; 3) en samling af dels udskrifter, dels afskrifter af de partier der ikke kom med i Danne-Virke I,

${ }^{18)}$ Henholdsvis Historisk Tidsskrift. Femte Række. Tredje Bind (1881-82) s. 366 note 2, og Historieforskning og Historieskrivning i Danmark indtil Aar 1800 (1931) s. 56-59. Derimod deler Molbech i sin indledning (s. XI) stiltiende Gr.s synspunkt.

${ }^{19}$ ) Laur. Nielsen har af typografiske grunde henført fragmentet til et tabt tryk fra 1504 (NTBB I (1914) s. 252). Trods en enkelt bedre læsemåde, som allerede Gr. fastslog, slutter Brøndum-Nielsen sig hertil (i sin bog s. 13). 
med mærkelige ord understreget, vel med anmærkninger for øje på de sidste blade er udskrifter, i bagvendt orden, suppleret op ved tilføjelse af det oprindelig udeladte; 4) et dobbeltblad mærket 19 der indeholder slutrimet til 1533-udgaven af rimkrøniken, det er muligt at det har været tænkt som afslutningen på artiklen og udvalget $\mathrm{i}$ DV $\mathrm{I}$; 5) et dobbeltblad med hyldestdigtet til Christian 1 og afvigende læsemåder (varianter) til senere partier $i$ teksten fra den nedertyske oversættelse $\left.{ }^{20}\right)$; og 6) et blad med varianter til $\mathrm{Hol}$ steinische Reimchronik (som Gr. kendte fra Nic. Staphorst: Hamburgische Kirchengeschichte II (1725) s. $118 \mathrm{ff}$.). De to sidstnævnte der - afhængigt af forskertemperament - må betegnes enten perifere eller mere end almindeligt spændende, er desværre vanskelige at datere. De er skrevet på papir fra I. Kool \& Comp., der i prædikenerne tidligst anvendes 1821 (jf. Nordisk tidskrift för bok- och biblioteksväsen XXXII (1946) s. 114), men det er ikke udelukket at de stammer fra den store aktivitetsperiode omkring Molbechs udgave.

Det det kunne være mest spændende at få svar på, er om Grundtvig har gjort sig videre tanker med Holsteinische Reimchronik, der trods mistænkelig lighed (polemik) i begyndelseslinjerne med den danske og trods en skildring med modsat fortegn af Valdemar sejr aldrig er inddraget $i$ den videnskabelige rimkrønikedebat. At Grundtvig på sine gamle dage omdigtede netop denne konges rim (jf. ndf.), kan skyldes ønske om en forherligende affattelse der ikke, som den gamle rimers, kunne give den holstenske modpart noget at hænge sin hat på.

Molbechs udgave 1825, som - foruden at hidføre en forsoning mellem ham og Grundtvig - pludselig præsenterede almenheden for et efter tidens forhold forsvarligt optryk af vor ældste danske bog, gav, som tidligere berørt, Grundtvig anledning til en grundigt forberedt anmeldelse i Nyt Aftenblad 1826 $6^{21}$, en af hans ridderlig-

${ }^{20}$ ) Af den nedertyske oversættelse skaffede Grundtvig sig på et eller andet tidspunkt efter 1825, idet der henvises til Molbechs optryk af dedikationsrimet $\mathbf{i}$ indledningen til hans udgave, men iøvrigt uvist hvornår, en afskrift (med fremmed hånd, fasc. 289), som han forsynede med filologiske blyantsnoter.

21) Det er skuffende lidt Morten Borup i sin ellers grundige monografi Christian Molbech (1954) har fået ud af dette og dets videre følger for de to, bortset fra udsoningen (s. $221 \mathrm{ff}$.). Det kunne være nævnt at Gr. ikke kom på prænumerantlisten (det gjorde derimod bl. a. Rudelbach), men at Molbech 25/3 1826 sendte ham glossaret særskilt (MolbGrBrevvexl. (1888) s. 133 ff.) efter digtet Broder Niels fra Soor, og at Gr. allerede $1 / 4$ begyndte at offentliggøre sin lange anmeldelse. - Senere i værket sav- 
ste handlinger. Det bør jo nemlig ikke skjules at det var en opgave han havde ment sig selv nærmest til, og kvalificeret sig til på lignende måde som de store oversættelser. I hans hænder var arbejdet rimeligvis blevet gjort med mindre kuriositet og med stærkere glød end Molbechs. Men han kunne se at Molbech havde gjort et ærligt arbejde, båret af ægte interesse; og så kunne han endda lukke øjnene for den drilske parentes om de ham så kære Jafet-vers!

Flerforfatterteorien er imidlertid det bærende $i$ afhandlingen $i$ Nyt Aftenblad 1826, og som Grundtvigs sidste videnskabelige ord $i$ sagen er det den hvis argumentation er lagt til grund for redegørelsen hos Brøndum-Nielsen (Om Rimkrønikens Sprogform og Tilblivelse s. 26-28), der fremhæver det underholdende i Grundtvigs fremstilling og hans blik for de talrige ejendommeligheder $i$ rimkrøniken, men slutter med en kritik af Grundtvigs utilstrækkelige filologiske vurdering:

Ulykken er blot, at han ikke skelner mellem væsentlige og tilfældige Forskelligheder, at han mangler de sprogvidenskabelige Forudsætninger for at vurdere de noterede Kolonner af Ord efter deres Værdi som mulige sproghistoriske eller individuelle Vidnesbyrd.

Det er klart at senere forskere både principielt og praktisk må henholde sig til forgængernes trykte indlæg, som de vota de hefter for. Der er bare i dette tilfælde det kedelige ved det at den trykte afhandling $i$ al sin charme tilslører det dygtigste og understreger det svageste $i$ argumentationen $i$ hovedudkastene. Det svageste skal jeg ikke dvale ved; det kan enhver filolog selv slutte sig til ved at sammenligne Grundtvigs afhandling fra 1826 med BrøndumNielsens værk fra 1930.

Foruden de bånd tidsskriftets pladsvilkår og faren for at lave en anmeldelse om til et selvstændigt arbejde lagde på ham, skyldes den saglige forringelse fra udkast til tryk to faktorer: forsætlig popularisering (han vil ikke skrive videnskabeligt, skønt han behersker stoffet tilstrækkeligt til det) og Grundtvigs arbejdsmetode, hvor det ene udkast påbegyndes efter det andet, og hvor et eller flere ark midt i fremstillingen lægges til side og erstattes med et nyt - righoldigere eller mere koncentreret, med ny indskud eller med forbigåelse af ældre. Sproglige eller saglige emner reddes jævn-

nes omtale af den del Molbech tog $\mathrm{i}$ det litterære udbytte af Gr.s Englandsrejser 1829-31, særlig som mellemmand mlelem Gr. og den engelske bibliotekar Frederick Madden, som var den der egentlig spændte ben for Gr.s angelsaksiske tekstudgaver (jf. min redegørelse Orbis litterarum V (1947), især s. 280-84). 
lig med over i den ny form, takket være understregning eller noter, men gerne på bekostning af den oprindelige stringens, fordi Grundtvig efterhånden forudsætter som almindeligt kendt hvad han selv fra begyndelsen har ræsonneret sig til. Det bliver til selvallusioner, som allerede her har et anstrøg af det koketteri der siden skulle gøre Brage-Snak berygtet. $\mathrm{Da}$ et citat til fyldestgørende dokumentation heraf ville fylde urimelig meget, må jeg henvise interesserede til at sammenligne Nyt Aftenblad 1826 s. 148 sp. $2 \mathrm{f}$. med et sent udkast, fasc. $288 \mathrm{nr} .6$ ( $8 \mathrm{v} 2-10 \mathrm{v} 2$ ), og et noget ældre, det tidligere omtalte fasc. $288 \mathrm{nr} .1$ ( 2 r2, i umiddelbar fortsættelse af citatet ovf. om rimkrønikens betydning for de store oversættelser, $-3 \mathrm{r} 2$ ), hvor malerens »snaksomme Ledsagerinde« endnu er et upersonligt »man«.

Til Bestræbelsen for en klar redegørelse der i almenlæselig form fremstillede Grundtvigs hovedtesis, et resultat der opnåedes ved stadige ombytninger i udkastene af afsnit og momenter, kom populariseringstendensen: angsten for at være pedantisk, jf. fasc. $288 \mathrm{nr} .5$ bl. $14 \mathrm{r}$ :

Dog, jeg føler det, Mikrologien er mere fristende, end Nogen skulde troe, og kan derfor ingenlunde laste den Frygt, jeg altid har havt for at gaae Elementerne saa nær, thi det er en Frygt jeg maa ønske alle skrivende Sprog-Granskere, Frygten nemlig for at blive en Pedant, og at skrive vaagne Læsere i Søvn.

Ikke mindst i dette, det længste af de bevarede udkast, og ældre end nr. 1 og 6, der synes at benytte det, opviser Grundtvig filologiske resultater man $i$ vor tid ikke ville behøve at skamme sig over. Han har både klargjort sig betydningen af ordfrekvens - det påfaldende $i$ at så almindelige adverbier som helst, hisset, især, maaskee og tit kun optræder én gang hver (14 r, jf. NAft s. 145 sp. 1 fodn.) - og ordklassefrekvens, hvor han på øjemål skønner over tætheden af verber og substantiver i krønikens første del, i modsætning til den overvældende mængde småord i dens sidste; det er kun den manglende procentudregning der adskiller ham fra den moderne statistisk-stilistiske skole. Karakteristisk nok fremstilles dette meget mere forblommet NAft s. 145. Til ordfrekvensstudiet hører for Grundtvig som for vor tids forskere også forholdet mellem synonymer. Den balance mellem ei og ikke som først BrøndumNielsen har undersøgt nøjere (i et videre perspektiv), strejfes (15 v2) sammen med aa og paa m. fl. Det ufuldførte fragment slutter $(17 \mathrm{r})$ med betragtninger over ortografi, med dvælen ved den ejendommelige fordeling af Jomfru og Jonfru på krønikens forskellige dele. 
I fortsættelse heraf bør det nævnes at Grundtvig forholdt offentligheden en værdifuld filologisk iagttagelse, som senere er blevet gjort af Marius Kristensen (Danske Studier 1919 s. 95 f.), efter at Molbech i v. 664 havde ladet raaer-kaal stå ukommenteret, og Holger Nielsen i sit glossar til udgaven af Stockholmerfragment K 41 (1895-1911) havde gjort ligeså med varianten agherkooll (selv om han havde ledt på sporet i selve udgaven ved til den - rigtige nedertyske variant at føje henvisning til det latinske forlæg). Når det tilføjes at Grundtvig ikke kendte varianten agherkooll, er det en pligt at citere hvad han (desværre kun i udkast, fasc. $288 \mathrm{nr} .6 \mathrm{bl}$. 12 r2) har skrevet om det:

Sagen er, at Saxo skrev om Dronningens tredie Brøst: qvod ciborum reliqvias dentium angustiis inhærentes stipite eruerit erutasqve commanducaverit, men heraf gjorde Rim-Smeden to Slemheds Tegn, ved at sige:

Tredie, hun stanged sine Tænder paa Straa, og Raaer-Kaal aad, som for hende laae.

Denne Kaal har Rimeren aabenbar fundet hos Saxo, ved at læse erucas for erutas, thi eruca fordansker Henrik Harpestræng ved Ager-Kaal, og enten nu Rimeren har foretrukket et andet Slags Kaal, eller aaer af en vittig Correxer er gjort til raaer, saa er dog Tingen lige klar.

Det er en sand engletålmodighed der kendetegner ikke mindst de filologiske forberedelser til denne anmeldelse. Først har Grundtvig sat sig ned og undersøgt hvordan det forholdt sig med rimstillingen $\mathrm{i}$ de forskellige kongerim (parrim, krydsrim og sekslinjede enheder med rimstillingen aab ccb, f. eks. Valdemarernes rim), og efter rimskifterne inddelt krøniken i 28 »Riim-Balke«; denne inddeling findes på de første blade af en tynd kvartprotokol, indlagt forrest i fasc. 300. Sammenlignet med Brøndum-Nielsens tabel (Om Rimkrønikens Sprogform og Tilblivelse s. 23 f.), frembyder Grundtvigs oversigt kun en ubetydelig afvigelse, der skyldes en sjuskefejl: Bjørns 4 vers $(2145-48)$ er regnet sammen med de foregående $\mathbf{i}$ stedet for med de følgende. Fejlen er altså intetsigende, men metoden den samme som er anvendt af en skolet filolog 100 år efter.

$\mathrm{Om}$ en endnu større flid vidner Grundtvigs ordudskrifter, som han karakteristisk nok har foretaget i folioprotokoller. De første er samlet under ét opslagsbogstav, med ordene indenfor de enkelte bogstaver noteret i den rækkefølge de står i teksten. Dette er sket i to kasserede christianshavnske skoleprotokoller, med skoleindførslerne afsluttet henholdsvis 1824 og 1823, og af Grundtvig mærket D og F, nu begge henlagt i fasc. 304. Fornemmelsen af forskellig sprogbrug i rimkrønikens enkelte 》balke« spores allerede i dispositionerne her. $\mathrm{D}$ begynder forfra på krøniken, $\mathrm{F}$ ved Regner lodbrogs rim (Mol- 
bechs udg. s. 132). Derefter opstilles - i fasc. 302 - ordlister efter de to første begyndelsesbogstaver, men indenfor hvert dobbeltbogstav efter forekommende rækkefølge i krøniken. Endelig bringer fasc. 301 ægte alfabetiske ordlister, med hver balk taget for sig. For fuldstændighedens skyld skal det mærkes at kun småord uden egentligt betydningsindhold er holdt udenfor listerne.

Hvad Grundtvig skulle bruge disse - møjsommeligt tilvejebragte - ordlister til, fremgår tilstrækkelig tydeligt af den trykte anmeldelse i $N y t$ Aftenblad 1826, der, ligesom de grundige udkast den bygger på, nyder godt af det enorme forarbejde. Det præcise mål med de nysomtalte ordlister, at undersøge om nogle af balkene var skrevet i mere folkeligt dansk end andre, fremgår af et afrevet folioblad (foldet efter benyttelsen), fasc. $300 \mathrm{nr}$. 20, hvor ordene er sorteret efter hvad der i det 15. århundrede kunne anses for fremmedord, og hvad der ikke - uanset dansk eller nedertysk oprindelse har kunnet erkendes som sådanne. Det bedste af ordmaterialet $i$ udkastene i fasc. 288 ledes af samme princip, som kladde til de ordlister der skulle påvise stilforskelle $\mathrm{i}$ enkelte balke eller grupper af balke. En anden sag er at Grundtvig indimellem rider sin etymologiske kæphest, med forkærlighed for ligheder med angelsaksisk. Disse steder virker som gengangere af hans noter i DV I, og hører ikke til dem der imponerer sprogforskerne. Det er derfor ikke af vejen at fremhæve udkastet fasc. $288 \mathrm{nr}$. 2, af Grundtvig selv mærket med et syvtal, hvor han åbent erkender sin egen begrænsning og - som en hovedgrund dertil - den utilstrækkelige adgang til sammenligning med andet gammeldansk materiale og behovet for et grundigere og fyldigere studium af dette:

Saameget troede jeg at burde sige, for at man strax kan see, om jeg har læst Rim-Krøniken med Opmærksomhed, og deraf slutte sig til, om det er Umagen værdt at agte paa mine Vink, og giør man det, vil man udentvivl snart forundre sig over, hvorledes det i Critikens Dage har kunnet falde nogen Boglærd ind, at tage en Bog, der saa klarlig røber sin blandede Herkomst, for een Mands Vark, og at antage den sletteste Rimer i hele Bogen for dens Mester. Om den for Resten er begyndt i det femtende, fjortende eller, som jeg mener, alt i det trettende Aarhundrede, derom nytter det ei stort at tale, før vore gamle Sprog-Mindesmærker ere anderledes bekiendte og sammenlignede, eller før man, ved Historiens Hjelp, kan giøre poetiske Grunde indlysende; men hvilket man end finder rimeligst, haaber jeg dog, man ei meer vil glemme, at Rim-Krøniken er et uskatteerligt Værk ei blot i det Danske Sprogs, men ogsaa i de Danske Rims og i det Danske Folks Historie.

Citatet skulle vise til fuldkommenhed at Grundtvig selv trak en ædruelig grænse mellem hvad han anså for bevisligt, og hvad hans indre syn sagde ham måtte være rigtigt (men altså ikke objek- 
tivt bevisligt), og fortjener at stå som hans sidste ord $i$ den rent sproglige vurdering. Dette gør det muligt i næste åndedræt at citere de to følgende afsnit, som heller ikke kom med i Nyt Aftenblad fordi de endnu mindre kunne indpasses $i$ en anmeldelse, men er den mest levende illustration af den betydning Grundtvig tilkender den danske rimkrønike:

Saalidet jeg nemlig vil yppe eller føre nogen æsthetisk Krig enten om hvorvidt Rimkrøniken, Kæmpeviserne, eller Høstgildet ${ }^{22}$ ) bør kaldes poetiske, saalidet kan jeg lade mig aftrætte, at de bedste Rim i Krøniken staae fuldelig ved Siden ad Alt hvad det Danske Folk har elsket og yndet som Skjalde-Tale, og, siden de fik det fremmede Ord i Munden, kaldt poetisk, saa enten er der ingen egenlig Dansk Poesi til, eller ogsaa er Rim-Krøniken, ligesom Kæmpevise-Bogen, en Blanding af poetiske og upoetiske, levende og livløse Rim, der ligesaalidet maae lastes som roses under Eet. Kun har Rim-Krøniken det store Fortrin, heeligiennem at være et ægte dansk National-Værk, medens vel den største Deel af Kæmpeviserne er om ikke Oversættelse, saa dog Efterligning ${ }^{23}$ ).

Ligesaa nemt, synes mig, det er, at bestemme Rim-Krønikens historiske Værd; thi maa skee havde den slet intet, hvis den havde deelt Skæbne med den Skotske, Lyneborgske, og Andre, der kom seent for Lyset og blev aldrig Folke-Læsning ${ }^{24}$ ), men ved i et heelt, og vel hardtad i halvandet Aarhundrede at være Folkets Liv-Bog i Fædernelandets Historie, har den Danske RimKrønike unægtelig hævdet sig en historisk Værdie, der ingenlunde staaer og falder med Dommen om dens Brugbarhed til lærde Øiemed. Den har nemlig derved erhvervet sig en dobbelt Vigtighed i det Danske Folks Cultur-Historie, deels som den af alle Historie-Bøger, der har virket mest paa FolkeMængden, og deels som et Speil, hvori vi see, hvad det er for en Behandling af Historien, der naturlig tækkes Folket, og som vi altsaa maae lægge Vind paa, om vi igien vil prøve paa at afhjelpe et Savn, der vel hardtad til Folkets ubodelige Skade, er blevet ældgammelt.

De sidste linjer, om rimkrønikens dobbelte vigtighed, er værd at tage op først. Den folkelige betydning herhjemme, fra bogtrykkerkunstens indførelse til Lyschander, skal der måske sættes et spørgsmålstegn ved. Men det er en opfattelse som stemmer vel med Grundt-

22) Thomas Thaarups dramatiske idyl til kronprinsbrylluppet 1790, der nød meget stor popularitet. Gr. har overstreget Th foran navnet.

${ }^{23}$ ) At vi her har kimen til det skel mellem »ægte « og senere viser dansk forskning har måttet trækkes med i sønnen Svend Grundtvigs folkeviseudgave, ses af det tilsvarende sted $i$ et ældre udkast, fasc. $288 \mathrm{nr} .3$ :

Kan man nu overbevise sig om, at vi i Rim-Krøniken har et MindesMærke af Tanke-Gangen, Rim-Konsten og Bog-Stilen i det trettende, fjortende og femtende Aarhundrede, da vil man ved Hjelp af den dog sikkert tildeels kunne bringe Orden i vort Kæmpevise-Chaos, og meget Lys i den saa $*$ forquaklede (skrivefejl: forduaklede) Materie, som Moders-Maalets Historie i Middel-Alderen unægtelig er blevet.

${ }^{24)}$ Rettet fra: Folke-Bøg. 
vigs hovedformål med at fordanske Saxo og Snorre. Også betragtningen af rimkrøniken som et spejl kan diskuteres. Fra et videnskabeligt synspunkt er den det nemlig på en anden måde: En større eller mindre del af kongerimene er skrevet som illustrationer af fyrstelige egenskaber eller mangler, sådan som de bl. a. kendtes fra det »fyrstespejl«, Secreta Secretorum, man i middelalderen kun alt for villigt tillagde Aristoteles. Erik emunes rim, hvor der direkte henvises til dette værk, regnede Grundtvig til de kedsommeligste; men så lidt som Molbech - der ellers i sin biblioteksgerning måtte have haft chance for at falde over en inkunabel med dette middelalderskrift havde han opdaget at der var adskilligt flere rim end dem der nævnede det mærkelige værk der stod i gæld til det, også nogle af de livligere. Men her røber Grundtvig sig som romantiker, ved at lægge et langt dybere værdiperspektiv ind end den tids mennesker ville have drømt om, et perspektiv der minder meget om det - gerne varierede - der går igen i stevet i Et Blad af Jyllands Rimkrønike, her citeret $\mathrm{i}$ den form det har i Amleth-afsnittet (str. 54):

\author{
Det er heel underligt et Sprog \\ Hun har den Dane-Sage, \\ Hun taler kun saa jævnt, men dog \\ Saa snildt om gamle Dage, \\ Et Speil hun fører i sit Skiold, \\ Hvor Nyaar sig med Hedenold \\ I Lignelse forene.
}

Denne gentagelse af tanken i rimkrønikepapirerne fra 1826 gør spørgsmålet om hvad der er oprindeligt, og hvad der er indskudt i Et Blad af Jyllands Rimkrønike, aktuelt på en ny måde. Måske er gåden, der spiller en stor rolle allerede i Til Sibbern (1811), det der har været med fra begyndelsen, og spejlet noget der er kommet til ved omarbejdelsen. Men det kan også tænkes at Grundtvig i 1826 arbejder sig tilbage $\mathrm{i}$ sin tankegang fra 1814 eller -15 .

Sammenligningen med Vedels eller Syvs folkevisebog er genial. Grundtvigs hypotese er derved den samme som Brøndum-Nielsens hundrede år senere (s. 96):

at Rimkrøniken skyldes en Række Sorø-Munke, af hvilke Broder Niels vel er den, der har lagt sidste Haand paa Værket: forfattet Rimet om Christiern I, det oprindelige Indledningsdigt, sandsynligvis tillige forskellige udfyldende Afsnit i det foregaaende - ligesom han kan formodes at have grebet ind rundt omkring med Ændringer og Udvidelser i de foreliggende Rim.

De to er altså fælles om det redaktionelle synspunkt: broder Niels har forefundet en række kongerim og komponeret dem som en hel- 
hed til aflevering til landets konge. Der hører enigheden imidlertid op: Grundtvig, der i dette kapitel er lige så stor romantiker som sin gode ven Ingemann, regner med successiv tilblivelse ned gennem århundrederne, lige fra Absalon pålagde Sorø-munkene at lægge vind på fædrelandets historie; Brøndum-Nielsen, der som sprogforsker anlægger en mere realistisk bedømmelse, konstaterer at sprogformen hører det 15. århundrede til, og forudsætter at munkene har udført arbejdet nogenlunde samtidig. For de yngste rimkrønikeforskere har spørgsmålet om en eller flere forfattere ikke klaret sig - BrøndumNielsen har selv siden sin bogs fremkomst taget forbehold overfor sin teori $^{25}$ ). Derimod formoder de tilblivelse i Margretes tid og supplering senere. Men i det arbejde der endnu forestår dem, er Grundtvigs redaktionsteori et incitament, også fordi den minder om det uløste spørgsmål om berøring mellem rimkrønike og folkeviser, og om det er forsvarligt at drage indbyrdes analogier.

Så kedeligt ville Grundtvig ikke have udtrykt det! Når han blev fyr og flamme ved redaktionsteorien, var det fordi den loftede broder Niels ud af den tid han havde levet $i$ - det femtende århundrede og gjorde ham til ét med alle senere danske, historisk bevægede digtere, og dem til ét med ham. Derved fik rimkrøniken sin betydning som folkelig bibel, jf. Grundtvigs tidligere nævnte chokerende bemærkning 1834 at han havde læst Rimkrøniken meget oftere end Bibelen. I digtet Broder Niels fra Soor, i anledning af Molbechs udgave (og skrevet inden anmeldelsen), med undertitlen »Efterskrift til den danske Rim-Krønike«, hedder det til sidst at »immer Broder Niels fra Soor / Gaaer giennem lukte Døre«. Meningen hermed er at den danske folkeånd virker igennem digterne, og billedet er opsigtsvækkende: overført fra Jesus der efter opstandelsen kommer ind gennem de lukkede døre (Joh. 20.26). Dette er ganske vist for 1832, hvor det menneskelige og det kristelige adskilles hos Grundtvig; men det virker sikkert blasfemisk på mange. Hertil må siges at kan man ikke affinde sig med dette sted hos Grundtvig, er kompromis umuligt; dertil indtager rimkrøniken en alt for central plads i hans forestillingsverden.

For den danske digter står Rimkrøniken da parallelt med Bibelen, som det engang hændte og fortalte, og som noget der fødes på ny i de enkelte slægtled. Begge dele er det derfor naturligt for digteren at nynne med på. Som Bibelen begynder ved Adam, hedder det om Rimkrøniken: „Fra Humble skal hun altid gaae, / Hvad end de Lærde sige.« I den anden retning kan rimkrøniken forlænges til nu-

${ }^{25}$ ) Jf. hans artikel om broder Niels i Dansk biogr. Leks. XVI (1939). 
tiden, og slutter naturligt med Frederik 6. Her var noget at digte med på!

Denne poetiske nyoplevelse og fortsættelse af rimkrøniken er ifølge Svend Grundtvig (PS V s. 390 f.) sket i to omgange, 1826 og 1834. Digtene fra 1826, som var lovet i Broder Niels fra Soor, mener sønnen at have samlet PS V s. 391-406, mens han har udvidet optrykket af kongerim fra Nordisk Kirke-Tidende 1834 med de udkast der er bevaret i fasc. 389 (PS VI s. 75-121). At disse sidste er rigtigt anbragt, er der ingen tvivl om, og det er morsomt at Grundtvig her endelig indfriede sit løfte om at føre krøniken à jour, så den sluttede med Frederik 6, selv om det sidste rim - og det eneste blandt de nyeste kongers - han fik med i trykken var Christian $7 \mathrm{~s}$. Derimod er det ikke lykkedes Sv. Grundtvig at placere afsnittene om de ældre konger i fasc. 388 efter deres tid, fordi noget af materialet - som nu ligger i fasc. 288 - var bortkommet for ham eller ligefrem unddraget ham; papirerne tilhørte jo nemlig hans stedmor, bispinde Asta Grundtvig, som tit handlede mere egenrådigt end forstandigt med dem.

Allerede Sv. Grundtvig tog dog (PS V s. 390 note 2) selv det forbehold at rimene 7-17 (Helge-Fenge) var fra et af de følgende år, og på de tilsvarende papirer i fasc. 388 har han skrevet $\gg 1826$ (28 ?)«. I det rent ydre stikker disse papirer af mod de foregående, både i skrifttræk, afmærkning (bølgestreg for de andres 3 prikker) og vandmærke (SEE, der i prædikenerne tidligst findes 1833); og hvad mere er: lange afsnit af de i sin tid bortkomne blade i fasc. 288 svarer til udvalget i Nordisk Kirke-Tidende 1834; det vil nedenfor blive dokumenteret for Skjolds rims vedkommende. PS V s. 391 -398 (de første kongerim, der slutter midt på en side med overskriften Gram) og s. $405 \mathrm{f}$. (et midt på en side afbrudt rim om Valdemar den store) er utvivlsomt fra 1826; de er skrevet på papir med Klippan-vandmærke med årstallet 1824 i, og dette synes Grundtvig at være holdt op med at bruge i 1826. Der ligger et opgivet udkast om Christian 2, som i rimkrønikens stil skulle have illustreret ordsproget »Strenge herrer regerer kun kort«. Da det er mærket med de tre bogstaver I.J.N. og har Honig-vandmærke, er det imidlertid sandsynligt at det er en udløber af Grundtvigs rimkrønikesysler i 1816 eller eventuelt en fortsættelse af disse.

Det vil herefter være forsvarligt at betegne de i PS V rigtigt placerede rim 1826-redaktionen, når man blot husker at det er en 
sandsynlighedsdatering. Vanskeligere stiller det sig med 4 blade $^{26}$ ) i fasc. 288, der aftrykkes nedenfor, men tidligere kun er benyttet Gr.symb. s. 305 for Jafetforjættelsens skyld og for at illustrere Dodanim = danskerne, som et folk der bor på havet. På dette punkt hæver den sig til større selvstændighed end 1826-redaktionen, mens den ellers virker mindre frigjort fra originalen. Datering ud fra ydre kriterier er meget vanskelig, idet vandmærket (CEIH) er det almindeligst anvendte igennem et par tiår. Afmærkning med 3 prikker (i st. f. I.J.N.) begynder i eller omkring 1823-24 (jf. Nordisk tidsskrift för bok- och biblioteksväsen 1946 s. 116); og dette skulle give nogenlunde sikker garanti for at det ikke er en udløber af rimkrønikesyslerne i Danne-Virke, ganske bortset fra at ånden jo er en anden, poetisk-fantasifuld i modsætning til den tidligere filologiske. På den anden side minder skrifttrækkene mere om oversættelsesårenes end 1826-redaktionens. Hvis man vidste hvornår Grundtvig fik sine første briller, kunne det måske hjælpe til løsningen. Det vil være rimeligt at trykke denne tekst, som vi vil kalde Dodanim-redaktionen, i sin helhed:

\section{Humble.}

Jeg Humble vil ei hav' forgiæt

Alt stammer Dansken fra Japhet

Den Noes Søn, der skjulde godt

Sin Faders Skam, da han var blot,

$5 \mathrm{Og}$ derfor $\mathrm{han}^{27}$ ) velsignet blev

Med Sem sin Broder, gild og giæv,

Alt som det lød fra Noes Mund,

Der talde ret af Hjertens Grund:

Sems Gud skal glæde Japhets Sjæl

$10 \mathrm{Og}$ give ham hos Sem Bopæl!

Den Glæde som alt Godt er hos

Det blev de Danskes Arve-Gods,

Som raader Bod paa Sorg og Kvid'

Og holder ud til evig Tid!

15 Det vilde Hav, og Frost og Rim

Ei kiøs de kiække Dodanim,

De giæsted Nord paa Bølgen blaa,

De bygde luunt, tog Pelse paa,

Og lige godt, fra Skov til Skov,

20 Paa Mark og Strand gik deres Plov.

De boed her i mange Aar

${ }^{28}$ ) Et foldet folioblad og to kvartblade fremkommet ved overrivning, alle forsynet med tre prikker, lakune usandsynlig.

${ }^{27}$ ) Rettet fra: høit. 
Før der blev talt om Kongens Gaard ${ }^{28}$ ), Indtil ${ }^{28}$ ) min Søn, som kaldtes Dan,

24 De tog til Konning og Formand \|

(v) Og sagde Alle med een Mund, Fra lille Belt til Øre-Sund,

Det alle Øer var til Gavn

At de tog Deel i Danmarks Navn

Saa Fynbo, Lollik, Sællandsfar ${ }^{30}$ )

30 Kiønt med hverandre Byrden bar ${ }^{31}$ )

$D^{2} r^{32}$ ) det saadan var overlagt

Med Falstring og med Fleer i Pagt,

Da kom der Bud til Kongens Gaard,

At Jyden havde trange Kaar,

35 For Tydsken var brudt ind med Vold

Og slagted Jyder som en Trold!

Det Bud de sendte til min ${\mathrm{S} ø n^{33}}^{3}$,

Fordi han var en Kiæmpe kiøn,

Og da han kom, som de ham bad,

40 Med Sværd og Skjold da vendtes Blad,

Saa de paa Hovedet kom ud

Som ikke faldt for Hugg og Skud,

Og Jyden loved fuldt og fast

At staae med Dansken Last og Brast!

45 Det Konge-Rig' i Eet og Alt

Til evig Tid blev Danmark kaldt, ${ }^{34}$ )

Det var en Lyst for Gubben graa

At see sin Søn saa høit paa Straa, \|

(r2) Og med den Glade i mit Sind

50 I Sælland sødt jeg slumred ind, Hvor jeg havde bo't i Lyst og Nød

Og skuet fuldmangen Aften-Rød'!

Der stander den Gaard til Yngres Gavn

Som $^{35}$ ) Humble har aatt, og gav sit Navn!

Dan.

55 Det gik, som Fader min har meldt, For Løn og Bøn jeg blev en Helt, Og sanked godt, som Træ og Bark, Hvad nu bær Navn af Dane-Mark. Hvad skal jeg sige meer derom:

28) Ovenover overstreget: Foruden Slot og Herre-Gaard.

$\left.{ }^{29}\right)$ Herefter overstreget: som.

30) Saa i marginen i st. f. overstr. Og, Lollik rettet fra Falstring.

31) Herefter to overstregede vers: $\mathrm{Og}$, kom med Nogen de i Kast,

Stod med hinanden Last og Brast! (Jf. ndf. v. 44).

32) Marginalrettelse for Dat, vel skrivefejl for $D a$; skrivefejl noteres ikke i det følgende.

$\left.{ }^{33}\right)$ Ovenover overstreget: Derfor de tyed til min Søn.

${ }^{34}$ ) Herefter overstreget: Og der jeg havde.

${ }^{35}$ ) Herefter overstreget: jeg. 
60 Mest rumler Vogn, naar den er tom,

Som Øster-Sø i Øre-Sund,

$\mathrm{Vi}$ nøies med en lille Mund,

Gud give altid Dannemænd

Hvad $\operatorname{godt}^{36}$ ) kan gaae igiennem den;

65 Og har for Riim og dagligt Brød

De liden Sorg og ingen Nød, ${ }^{37}$ )

Og spræk af Kløgt, og spræk af Blæst,

Heelskindet har dog immer bedst!

Gid Mund kun aldrig gabe saa,

70 At Haand dertil kan ei forslaae,

Da Kongen over Lyng og Lund

Skal kaldes $\mathrm{s}^{38}$ ) i Belt og Sund, \|

(v2) Og bytter ei, dog Hans er smaat,

Sit Konge-Rig' med nogen Drot!

\section{Humble Dans-Son.}

75 Her kan man høre, at Danske Mænd

De kloge vare, som de er end,

Thi Riget vilde de hav' saa frit

At Ingen skulde det kalde sit,

Som i sin Gierning ei var saa from,

80 At han det fik for sin Manddom

Og keiset blev dertil med Ret

Af gode Mænd, som Lov var sæt!

Da Fader min var lagt paa Baar

Af ret Hel-Sot, og ei af Saar,

85 Da satte mig Daner høit paa Steen,

Det kaldtes Stol med stærke Been,

Thi som den fast i Jorden laae,

Saa skulde Tro og Love staae.

De gav i Haand mig Spir og Sværd,

90 Men ei $^{{ }^{39}}$ ) mig hued Herre-Færd,

Og meer end man mig troed til,

Jeg skyed Krig og Lykke-Spil,

Men gjorde hver Mand Ret og Skiel,

Og tænkte paa det Heles Vel!

95 Fuldmangen Kæmpe det fortrød

At jeg var i min $\mathrm{Hu}$ saa blød.

(r3) Dem tykdes, der var bedre Kaar

I Broder min, for han var haard,

Thi satte mig de Stol for Dør,

${ }^{36}$ ) Rettet fra: der; lille begyndelsesbogstav viser at det er adverbium (o: nemt).

${ }^{37}$ ) Ovenover overstreget: Da har for Vidskab og for Brød De liden Sorg, og ingen Nød.

38) Ovenover overstreget: Skal nævnes stor.

$\left.{ }^{39}\right)$ Marginalrettelse for: Men lidt. 
$100 \mathrm{Og}$ han blev det som jeg var før;

Men hvad jeg blev, var aldrig han, Fornøiet med den ringe Stand,

Og hvo ei nøies kan med Lidt,

Om han faaer Nok, det skeer ei tit!

\section{Lotther.}

105 Med Synd det kom, med Sorg det gik, Det Konge-Spir med Ran jeg fik, Min Trop og jeg blev snart usaatt, To haarde Steen ei male godt, Og meer til Skade end til Gavn

110 Min Kæmpe-Haand bar Konge-Navn!

Jeg lidt mig brød om Ret og Skiel, Men panted ud, og slog ihjel, Til magtesløs jeg sank paa Baar For Morder-Haand, med Bane-Saar!

\section{Skjold.}

115 Mig kaldte Mange Odins Son, Og jeg mig kalder Hans $i$ Lon; Thi da som Dreng ved Danmarks Styr Jeg spurgde om min Et og Byrd, Da sagde mig de Gubber graae:

120 Din Vugge gik paa Bølgen blaa, II

(v3) Men hvem der lagde dig deri, Det veed kun Gud, og ikke vi! Der kom et Skib til Isse-Fjord For fulde Seil, med dig ombord,

$125 \mathrm{Og}$ ellers ingen Moders Sjæl, Saa Skibet skiøddede sig selv! Der laae du spæd i Purpur-Svøb Paa Mos og grønne Bøge-Løv, Til Hoved-Pude havde du

130 En Tvilling-Neg af Byg og Rug, Og Vuggen var for Resten fuld, Af Staal og Jern, og Sølv og Guld, ${ }^{40}$ ) Af Rustninger og Klædebon, Som røbed Alt en konstig Haand!

135 Det var just i den dyre Tid, $\mathrm{Da}$ rundt om Land var Tvist og Splid, Da uden Lov, og uden Drot, Hver gjorde hvad han fandt for godt, De Store sloges om de Smaa,

10) Ovenover overstreget: Af Rustninger, af Sølv og Guld. 
140 Og Smaa-Folk om en Gaase-Taa!

Thi var du, under Konge-Flag,

Os som en buden Hellig-Dag,

For Vaande stor vi skimted' Bod,

Vi satte Negen paa sin Rod,

$145 \mathrm{Og}$ satte dig med Gammen op

Til Konge-Sæde $\mathrm{i}$ dens Top,

Og raabde: længe leve Skjold,

Os til en Lande-Varger bold!

Jeg voxde op i Kongens Gaard,

150 og før jeg fyldte femten Aar,

En Bjørn jeg bandt i Skoven stærk,

Det var slet ikke Børne-Værk. \|

(r4) Og stille hen det var min Agt Som Daners Skjold, af al min Magt,

155 At ramme Rigets sande Gavn, Hvorfor jeg bar mit Konge-Navn!

Jeg røgted Vangen for Ufred, Og gjorde ingen Kat Fortræd. Jeg elskde alle Dannemænd,

160 Som Ridderen, saa og hans Svend, ${ }^{41}$ ) Og Alting godt hos mig forslog, Endskiøndt jeg heller gav end tog, Saa naar min Foged var for haard Kom Fattig-Folk til Kongens Gaard,

$165 \mathrm{Og}$ gik saa glade ud igien,

Som de kom grædende derhen!

Derfor, jeg tænker, jeg faaer Lov, Saalænge der er Fugl i Skov,

Og beiles skal til Skjoldung-Navn,

170 Der i den Danske Konge-Stavn,

Saalænge under Hjerter smaa

Min Vugge gaaer paa Bølgen blaa!

\section{Gram.}

Hvo Fader ære vil i Grav,

Skal slægte paa hvad han kom af,

$175 \mathrm{Og}$ er det godt, da faaer han Roes

Med Rente for sit Arve-Gods!

Den Tid jeg Danmarks Krone fik,

Jeg i min Faders Fod-Spor gik

Men tykdes dog, at bedre Hold

180 Der var i Sværd, end som i Skjold

Til Fiende-Frygt og Lande-Fred,

Som spørges kan og vare ved.

(v4) I Sverrig sad en Jette styg

Paa Konge-Stol, hed Seiertryg,

41) Herefter overstreget: Jeg helst med begge Hænder gav, Og gjorde kun paa Hjerter Krav. 
185 For han med Trolddom saa var vreed,

At Staal og Jern ei paa ham beed

Men død han trilled dog omkuld

For Kiølven af det røde Guld,

Som jeg dertil mig giøre lod,

190 Og gav med Bane-Saar ham Bod ${ }^{42}$ )

En sammenligning med den originale krønike viser betydelige udsving i begge retninger. Grams rim kan man næppe dømme om, da det må betragtes som ufuldført, skønt stoffet fra rimkrøniken næsten er udtømt, og Skjolds - det voldsomst opsvulmede - skal gemmes til senere omtale, det er på 58 vers mod originalens 22. Tilsvarende er den yngre Humbles vokset fra 26 til 40, mens den ældres er svundet ind fra 66 til 54, Dans forkortet med 2 vers fra 22 til 20, og Lothers med 4 fra 14 til 10. Der er en tydelig plan i forkortelserne: det er først og fremmest udelukkelse af al datering, som mange steder $\mathrm{i}$ krøniken går $\mathrm{i}$ bredden, og som Grundtvig $\mathrm{i}$ Molbech-anmeldelsen tillagde en Søren Matthisen, velvilligt ihukommende den gamle regnebogsforfatter! Sammen med dateringen forsvinder også parallellerne med det Gamle Testamente, dog med to undtagelser: Jafetforjættelsen og (v. 21-24) levn af rimkrønikens forestilling om at Danmark havde været regeret af dommere inden det fik konger. Trojansk afstamning vil Grundtvig jo ikke have noget med at gøre, derfor kan han af Dans rim kun bevare de to første vers, men tager resten på sin egen kappe. Til gengæld er den yngre Humbles vers kun en udbygning af rimkrønikens, om den alt for milde fyrste der ikke kan vinde sit folk for sig, men styrtes af sin onde broder, $\mathrm{i}$ hvis rim Grundtvig uddyber det svage syndsperspektiv.

Det Grundtvig navnlig kan bruge, er den nationale front mod tyskerne, som er så stærkt udtalt i Humbles rim. Men mens det dèr kun galder den første konges magt og ry, er det for ham alle øboernes indsats der er hovedsagen, sådan som de opregnes i Lavrids Koks Danmark, deiligst Vang og Vænge, som han selv havde trukket ud af glemslen i første hefte af Danne-Virke. Hos Grundtvig låner Dans rim glans af hans hæder $i$ det foregående; det er en populærfilosofi over dansk mentalitet kontra den tyske, som han tænker på med v. 67. Ånden i dette kongerim mere end noget af de andre er en genkaldelse af Langt hoiere Bjerge.

Til sidst nogle få bemærkninger om Grundtvigs stilistiske ind-

42) Ovenover overstreget to udkast til v. $189-90$, det første som v. $189 \div$ dertil, det andet som v. $189+$ v. 190: . . med Bane saa . . . 
sats, som også gælder de følgende redaktioner hvor han langt overgik sit moderate tilløb her. Stærkest mærkes de i Skjolds rim, hvor det f. eks. med et yndet udtryk i oversættelserne (Snorre II s. 360 , om en biskop(!), foruden de to eksempler i Ordbog over det danske Sprog) - siges at Skjold kom som en buden Helligdag; udtrykket er så velvalgt fordi det er en folkelig vending der i sig selv anslår en feststemning. Eller hvad mener man om sammenligningen af Danmark og Østersøen, der begge har den beskedne mund? Forøvrigt lægger man også mærke til et ældre lag i ordforrådet: i v. 38 optræder kiøn og i v. 79 from, begge i deres gammeldanske betydning dristig eller tapper. Mens disse er direkte overtaget fra den gamle krønike, er der andre af mere norrøn klang (f.eks. sæl v. 72) der tilhører Grundtvigs (ældre) poetiske stil, og giver et vist patetisk præg som endnu afbalancerer det folkelige.

Det ser ud som Grundtvig en overgang har villet bryde overtvært, og lade de gamle rim ligge til fordel for i det mindste ét af de nyere. De partier af rimkrøniken som i virkeligheden er sekslinjede strofer (med rimstilling aabccb), havde han ikke høje tanker om, og til dem hørte vore ypperste kongers, Valdemarernes. Iblandt de af Sv. Grundtvig benyttede rim som sandsynligst dateres til 1826, indtager Valdemar den Store (PS V s. $405 \mathrm{f}$.) en særstilling ved at være nydigtet $\mathrm{i}$ andet versmål end det oprindelige, nemlig i parrim, og have overtaget noget af Jafetforjættelsen, i en form der vel ikke nævner Dodanim, men dog ligger nærmest op ad den version hvori de forekommer.

Det øvrige af den ægte 1826-redaktion (PS V s. 390-98, som foregående rim hjemmehørende i fasc. 388) er en videreførelse af Dodanim-teksten, hvad der klarest ses ved en sammenligning af de tos Lother-afsnit, hvor det nu er lykkedes Grundtvig at omforme den refererende indledning til en sentens i rimkrønikens ånd. Enkelte steder vender Grundtvig tilbage til den oprindelige form, således i hovedet til Humbles rim hvor det at Noa lå blot er rettet tilbage til at han lå bar. Endvidere er han blevet mere lydhør for de gammeltestamentlige paralleller. Både Sarug, Abrahams oldefar, som jævnaldrende med Humble, og Gideon som en ligestillet dommer-høvding vender tilbage. Indimellem har Grundtvig, egentlig mod sædvane, fået plads til en dansk landskabsskildring:

Saa vide de foer end paa Havets Hest

De Hjemmet dog funde af Alting bedst,

Fuldgierne de talde derom i Kveld,

hvor prægtige Skove der groe paa Fjeld,

Men immer dog fandt de, i Bøge-Læ, 
At Danmark havde det feireste Træ!

Fuldgierne de skiænked den klare Viin,

Og saae, hvor den voxde paa Skrænt ved Rhin,

Ved høie Møen med hviden Bryst,

De lydt dog loved den danske Kyst

de frit bekiendte, til daglig Brug

langt bedre end Vin er Byg og Rug.

Kontrasten mellem folk og vilkår er skarp, men traditionel; vi kender den fra Oehlenschlägers terziner i Aladdin og Audens overtalelsesforsøg i Hakon Jarl. Det er bemærkelsesværdigt at tvillingneget i Skjolds rim i Dodanim-redaktionen var bundet med byg og rug; og dér betød det nok endnu fællesmonarkiet, så byggen var Norges andel, en faktor der kunne fremkalde overvejelser om denne ældste fri bearbejdelse var nogenlunde samtidig med Nyaars-Morgen, hvor Grundtvig jo taler til sine frænder »Paa Mark og paa Fjeld«. I den tekst vi her har med at gøre, hvor neget senere viser sig at være bundet af alle fire kornsorter, er der ingen tvivl om at både byg og rug er danske. At det netop er rhinskvin der stilles $\mathrm{i}$ kontrast, er ingen tilfældighed: til den nedertyske oversættelse Christian 1 fik foræret i 1477 var forfattet en fortale, hvor munkeforfatteren gør undskyldning for at han hverken har drukket af den franske vin, eller af den der gror ved Rhinen. I Grundtvigs øjne er dette ikke noget at gøre undskyldning for, tværtimod!

Ellers er det i 1826-teksten Grundtvig en fryd at udpensle hvordan nybyggerfolket slår sig ned, og efterhånden får tid til de ting der kan vente til efter det første ryk, f. eks. at bygge kongsgård. Som Humble i foregående redaktion var beæret af at hans søn var kommet »saa høit paa Straa«, føler han endnu, dog i rimkrønikens egne ord, hvad der gør det naive mindre naivt. Hos Grundtvig ligger der nok en følelse bagved, af at kongen påskønner den enevoldsmagt borgerskabet havde skænket Frederik 3 .

I 1834-udkastet, men ikke i trykmanuskriptet, Collin 219, $4^{\circ}$, eller rentrykket, har vi for eneste gang fundet Jafet-forjættelsen slettet. Men endnu en overraskelse bereder dette: Angel, Humbles anden søn, hos Saxo og i rimkrøniken opnævner for anglerne, som ikke var kommet med i Dodanim-redaktionen, men stod på rette plads i 1826-redaktionen, har fået sine vers strøget i det afsluttede 1834-udkast, men alligevel er de atter rykket ind i Collin 219, $4^{\circ}$ og i rentrykket. Det er som også Grundtvig har kunnet blive træt af forfaderhyldesten, med eller uden forjættelser. Givet er det at det der efterhånden interesserede ham mest i Humbles rim, så han også fyldte Dans med det i stedet for det kasserede trojanske 
stof, var kampen mod tyskerne, som tiltager $\mathrm{i}$ styrke ved at fronten i Dans rim nu drejes fra det filosofiske område til det politiske. For fuldstændigheds skyld skal tilføjes at den yngre Humbles og Lothers rim i 1826-redaktionen formelt i høj grad frigør sig fra forlægget, mens der i 1834 - modsat rimene efter Skjold eller i hvert fald Gram, hvor Dodanim-redaktionen har tjent som forlæg for 1834-teksten (v. 179-80 høres bag »Dog var jeg mod den Herre bold / At ligne vel som Sværd mod Skjold«) - er en bevægelse tilbage mod urformen, så længe denne er absolut forenelig med en jævn og underholdende folkelig fremstilling.

Til en forsvarlig redegørelse for den enestående historisk-poetiske bedrift Grundtvig i seks etaper fik ud af Skjold-sagnet, vil det være naturligt først at se på det temmelig beskedne forlæg i den gamle krønike, dennes v. 151-72:

Theth bør hwer koning at haffue til sedh, beskerme syne land och holdhæ fred, Och wide och gøre syn almw gaffn, ffor hwilkæ han ber sit konningæ naffn.

155 Jegh ælgstæ mit rigæs gode men, iegh halp och trøste them hwer oc en.

Fattigæ folk giorde ieg och soo; thi mwnne theth meg wel meth allæ goo. Then, som arm och vsell wor,

160 iegh gaff hanum gønst oc gode swar. The, theres gield ey gielde kwnde, ieg halp, at the ther gaffn aff fwndhe. Allæ wloffuer och alskøns vræth, them skyckede ieg wed en bedræ sæth.

165 Jegh war ey mere en $\mathrm{xv}$ aar tha ieg for forst at bede raar; Megh kom so stor en biørn i modh, hannum slo ieg neder for myn fodh. Jegh bant hanum meth myt bælthæ ful vell,

170 och fick hannum mine stalbrødher at sla i hiell. Jegh døde aff sott och ey aff swærd, so gik megh i myn lewende færd.

Skjolds rim hører til de typiske: Det begynder med en læresætning (v. 151-54), holdt i bred almindelighed, hvad der kan være rimeligt nok da Skjold åbner den egentlige kongerække og de foregående kongers rim enten er imperialistiske eller samfundsmæssigt konstaterende, eller negative (Lothers): hvordan en fyrste ikke må være (jf. også Hans Brix: Analyser og Problemer III (1936) s. $138 \mathrm{f}$.). Kongen er til for almuens skyld, ikke omvendt, og Skjold 
har indlagt sig yndest ved at tage sig af fattigfolk, fremfor alt ved at holde hævd over retsbeskyttelsen. Men han er ikke veg som Humble (2); det har han vist ved at binde en bjørn som femtenårig. Rimet har den obligate slutning om kongens dødsmåde. $\mathrm{Og}$ så må vi ikke forlade det uden at mindes monologformen, der, som tidligere berørt, er et særkende for den danske rimkrønike og Lilla Rimkrönikan, samt at forskellen på de to poetisk set ikke er ringere end Grundtvig ville gøre den. Rimet er ideelt, for der er hverken for meget til at hemme Grundtvigs fri initiativ - det kneb jo i den aldre Humbles - eller for lidt til at tjene som skabelon for en handling eller episoderække.

Så tiltalende denne kongeskildring har virket på Grundtvig, så var den jo holdt $\mathrm{i}$ bredeste almindelighed, uden et eneste individuelt træk. Derfor udfylder han Skjolds biografi med oplysninger om hans oldesøn, »Frode haddings søn hyn geffmildhe«. Sentensen er i hans tilfælde et lån fra Secreta Secretorum, kravet om at fyrsten skal give efter evne - »juxta posse tuum《, som »Aristoteles« skrev til »Alexander«, og - for krønikens egen regning kongens og undersåtternes gensidige forpligtelser:

Hwer then førstæ, som krona bær,

250 bør then ath giwe som tørtig ær, Then gott ær werd oc gott fortiæn, och rænthen fforslar vd aff hans læn.

Thi giorde meg danske then hedher oc prijs,

for ieg wor ther tijl klog oc wijs,

The gaffue meg krone oc koningæ naffn;

260 theth kom them selffuer tijl megeth gaffn.

Sådan som Grundtvig ved de forskellige lejligheder har tilrettelagt Skjolds rim, har det været $i$ to halvdele med skiftende rækkefølge, hvoraf den ene nogenlunde dækkede den gamle krønikes fremstilling, mens den anden udnyttede hans øvrige viden og endnu mere hans myteskabende evne. Det var her Grundtvig gjorde sit poetiske kup, omdigtningen og videretænkningen af det gamle kvad om Beowulf. At han fandt det nødvendigt, skyldtes naturligvis i første række et poetisk syn: men en tungtvejende årsag har sikkert været et ønske om at revidere den overskrift han forefandt $i$ den gamle krønike: at Skjold ansås for Lothers søn. Det ville nemlig i hans øjne være et katastrofalt brud på modsigelsens grundsætning. Et holdepunkt havde han i Snorres Edda, hvor Skjold nævnes som Odins søn; men kun ved hjælp af en myte kunne han sandsynliggøre det. 
Denne myte fandt han i Beowulf, som han kunne udenad fra sin egen oversættelsestid (Bjowulfs Drape, 1820). Første sang i Grundtvigs oversættelse slutter (s. 4-6) med at Skjolds bedrøvede kæmper søsætter et rigt udrustet skib med den døde Skjold om bord, sådan som han selv i levende live har budt dem. Dette smukke sagn er i Grundtvigs gendigtninger af rimkrøniken kun indlemmet i rimets mest omfattende form i NKT 1834 (optrykt PS VI s. 79), og der endda som en uvis fremtid, idet situationen samler sig om Skjold og hans kæmper, der lytter til deres fyrstes befaling. Dette rører forøvrigt ved en kompositorisk vanskelighed. Den lange Skjoldmyte, som vi skal tale om, forliges mindst lige så dårligt med digtets jegform; men $\mathrm{i}$ alle redaktioner, indtil det blev en løsrevet sang, er der skabt en fiktiv ramme. I Dodanim-redaktionen fremstilles det hele i 2. person af de gubber han har spurgt om sit ophav; i 1826-redaktionen (jf. PS V s. 396) er det en af to mulige forklaringer, og i 1834-teksterne (jf. PS VI s. 78) er det en hvidhåret skjald der kvæder visen om det for ham. - Men det er værd at understrege at det er de to ældste tekster der skarpest fremhæver at han er sendt af himlen. I samme retning peger at det kun er i disse skibet løber ind i Isefjord. Den var for Grundtvig helliget på særlig måde efter at han i Roskilde-Riim havde skildret Galilæas bæk (Ez. 47.8), som lægte vandene, og på sin vej også nåede frem til Isefjord, hvor den havde fået et væld til at springe, som Roskilde domkirke og by igen var bygget over. Derfor er det mindre sandsynligt at skibets mål er den gamle hedenske hovedstad, Lejre.

Grundlaget for myten om Skjolds komme er yderlig spinkelt; des mere imponerende er det at den er lykkedes så fuldkomment. Bedriften består $\mathrm{i}$ at Grundtvig har skabt en situation der $\mathrm{i}$ poetisk værd stod mål med Beowulfs skildring af Skjolds bortfærd, men samtidig i kraft af emnet havde en frejdigere tone og mere æventyrmæssig fremstilling. Der kom hans etymologiske raptus, det mest vidtdrevne udslag af hans associationstrang (jf. Gr. s. fil. 1. kap.), ham til hjælp ved at forære ham neget. Om Skjolds herkomst oplyser det angelsaksiske kvad ikke andet end at han er Scyld Scefing, Scefs søn Skjold. I navnet Scef griber Grundtvig nu ordet for neg, nyengelsk sheaf. Kombineret med sagnet om at Skjold er kommet til landet med et skib, uden at nogen vidste hvorfra eller hvordan, bliver det til at det lille barn er kommet sejlende med et neg under hovedet. Det er et rent poetisk fund, for Grundtvig fastholder ellers den videnskabelige forklaring på ordet Scefing.

Neget er fra begyndelsen (Dodanim-redaktionen) et tvillingneg, af rug og byg, der symboliserer det tabte, men i ånden stadig be- 
stående fællesmonarki. Idéen kommer tilbage i 1834-udkastet; men i de resterende tekster er det bundet af alle fire kornsorter, og kan symbolisere de fire stænder, eller bare være et udtryk for fuldkommenhed. At neget er bundet »med Ax og Straa«, er et vidnesbyrd om at Grundtvig selv tydeligt ser det for sig; men denne tilføjelse kommer først ind i udkastet 1834. I situationsskildringen har det en dobbelt funktion: Dels er det den lille drengs hovedpude, dels sætter folket ham oven i det da han bliver hyldet. Dette understreger fredsstemningen, $i$ forventning om en mild og landsfaderlig regering og gode afgrøder. I det hele taget er det i udkastet og trykket 1834 den billeddannelse vinder hævd som bliver stående i C. J. Brandts endnu ufuldkomne strofiske optryk 1848 (Rim og Sange til Fædrelandets Historie, første tekst med begyndelseslinjen I gamle Dage det var engang, jf. Steen Johansens bibliografi I s. 304) og Kristian Køsters første syvstrofede 1865 (nr. 51 i Et Hundrede Danske Sange). Det er således først i NKT 1834 at linjerne om de godes og de ondes vilkår dukker op og hele den stilistiske afpudsning sker. Dette afsnit af udkastet i fasc. 288 bringes til sammenligning med den trykte form (genoptrykt PS VI s. 78):

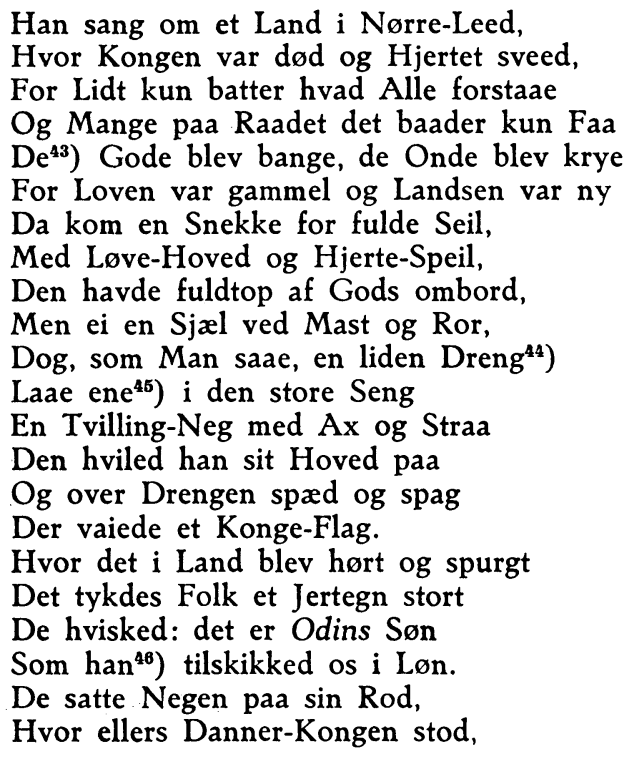

43) Skrivefejl: Det; blev (1) i samme vers er rettet fra: var.

44) Ovenover overstreget: Der laae kun lavt en liden Dreng.

${ }^{45}$ ) Rettet fra: Sov ene.

$\left.{ }^{46}\right)$ Herefter overstreget: os. 
De Største tog den Mindste op

Og satte ham i Axe-Top.

Da spurgdes Nyt, da hørdes Gny

Da lød det mildt i høien Sky:47)

Hil være dig, vor Konning bold,

Og længe leve Danmarks Skjold!

En sammenligning med disse vers og trykket vil være nem, fordi den ordlyd vi kender fra sangen 1865 næsten overalt stemmer med prøverne i NKT 1834, højdepunktet i Grundtvigs gendigtningsforsøg med rimkrøniken. Teksten ligger nær nok den trykte til at være kladde; men samtidig røber den hvilket stilistisk arbejde det kostede Grundtvig at skrive jæunt og utvungent, et arbejde der ganske vist med modsat formål og resultat - kunne nøde ham til at gøre fælles sag med dem han havde railleret over i Nyaars-Morgen, de »sprænglærde Smaa, / Som ikkun paa Stile / At file forstaa«. Men når vi ser hvor ihærdigt han har pudset sin egen stil af for at gøre den folkeligt tækkelig, sander vi ordene fra samme digt, at »Krøniken rækkes / Og tækkes de Smaa«, de taknemmelige læsere med de opladte sind, dem han allerede havde tænkt på med Amleth-stroferne i Et Blad af Jyllands Rimkronike.

Sagligt er det meste kommet ind i udkastet, men præsenterer sig af stilistiske grunde bedre i trykket. Når vikingeskibets dragespejl, både $\mathrm{i}$ den utrykte og den trykte redaktion 1834, viger for hjertespejlet, er det for at gøre snekken helt dansk ved at den har begge attributterne fra rigsvåbnet. Men ingen af dem har fået med at flaget er hvidt og rødt som Freias kind. Dette træk indlemmede Grundtvig først 1865, skønt det er det vigtigste overhovedet på grund af sin henvisning til legemsvarmen og farven i vort flag og det tænkte hedningbanner (jf. Gr.symb. s. 77), og skønt han selv i 1826 havde talt om farverne hos det sovende barn, et vidnesbyrd om hvordan symboler kan glide ud hos Grundtvig, for først at vende tilbage mange år efter.

Kulturbilledet trækker i to retninger. Skitsen af snekken og pragtgenstandene og våbnene om bord, for slet ikke at tale om våbengnyet da Skjold hyldes, skal virke oldnordisk, i 1826 understreges det af glosen Løftingen, der hører til det norrøne ordforråd Grundtvig som helt ung havde boltret sig i. Forestillingen om at Skjold er Odins søn må i denne forbindelse ikke glemmes. Men ægte oldnordisk er kulturbilledet på den anden side langtfra. Der er ikke få træk af almueskildring i dens obligate form fra Thaarups Høstgildet,

${ }^{47}$ ) Ovenover overstreget: Da raabdes der i høien Sky. 
der nævnedes som ligestillet med rimkrøniken og folkeviserne i et af de ovf. citerede udkast til anmeldelsen af Molbechs udgave. Hvor der er våbengny i 1834-redaktionerne, samledes i 1826 bønder og oldermænd om barnet. Dette falder i god tråd både med rimkrønikens skildring af Skjold, og med fornemmelsen af at det af navn er Skjold men af gavn Frederik 6 Grundtvig skildrer. Således hedder det jo i Dodanim-redaktionen at Skjold »gjorde ingen Kat Fortred«, de ord Caroline Amalie fik Grundtvig til at stryge i mindedigtet over Frederik 6 (jf. senest Steen Johansens bibliografi II s. 154). Over den humoristiske virkning dette udtryk har haft på samtid og eftertid, er man tilbøjelig til at glemme hvilken dyb og ægte følelse der lå bag. Man genkender også Frederik 6 i omsorgen for de enkelte husstande. For Grundtvig er linjen ubrudt fra Skjold til Frederik 6, og deres tidsaldre spejler hinanden, en kendsgerning der bør huskes både ved analyse af jubilæumsdigtet Gylden-Aaret (1834, jf. Gr.symb. s. 76-79) og Den udødelige Danne-Konge (1833), hvis perspektiv uddybes i Grundtvigs Skjold-rim, der ganske imod rimkrønikens princip sluttes med Skjold i levende live. I rimkrøniken er perspektivet dennesidigt: den $i d y l$, som Frederik 6s undersåtter befandt sig så vel ved. Digtet $i$ sin helhed viser at det er det milde og rolige Grundtvig foretrækker, han vil nødig i affekter.

Lånene fra rimkrøniken har Sv. Grundtvig markeret ved petit. Ved siden af landsfaderskildringen, og i kontrast til denne, er der bjørnen der bindes. De to første udkast følger traditionen: at Skjold på en råjagt møder en bjørn som han binder, hvorefter hans kammerater kommer til og nedlægger den. Men i det sidste udkast og trykket bagateliseres råjagt, som noget der passer for ganske unge mennesker, Skjold har andet at bestille! I det sidste udkast binder Skjold den i sit bælte, hvorved den jo kvæles; det er ikke usandsynligt at Grundtvig har tænkt på dronningen under Stærkodders bælte. I trykket afdæmpes præpositionen til med.

Også 1834 er rimet om Skjold Grundtvigs virkelige bedrift; det om Gram har, som nævnt, overtaget pointen fra Dodanim-redaktionen: at der til læren i middelalderværket at man skal slægte fædrene på, føjes at Gram supplerede sin far: »Dog var jeg mod den Herre bold / At ligne vel som Sværd mod Skjold.« Rimene om Svipdag og Hading er tilsvarende udkast-varianter til Skjolds; det om Hading skatter i høj grad til Nyaars-Morgen, i sig selv en interessant kendsgerning, som viser hvordan Grundtvig mente krøniken skulle udbygges med digternes bedste ydelser omstillet efter rimkrønikens tone og versbygning. Frode Hadingsøns rim, der lige så lidt som 
Grams er blevet trykt, er en ren nydigtning, over to af situationerne i Saxos fremstilling af denne konges historie: hvordan Frode vandt guldet fra dragen, og hvordan han - hos Saxo langt senere - i en kamp mod briterne strøede det på slagmarken og siden genvandt det. Som konklusion anvender Grundtvig kenningen Frodes mel, der for øvrigt i Snorres Edda tilskrives Frode fredegod. På anden måde er Halvdan »Gamle« (rettet fra »Høie«) omtydet fra Saxos og rimkrønikens onde brodermorder, til den Haldan som i 10. sang af Bjowulfs Drape sender Hengest til England, og på samme måde identificeres Ro, efter at rimkrønikens beretning om grundlæggelsen af Roskilde er sket fyldest, med den Hrodgar trolden Grændel huserer hos i det angelsaksiske heltedigt.

Vi er dermed nået til »Helge Hundings-Bane«, af hvis rim Sv. Grundtvig kun mangler 6 indledende vers PS V s. 398 (om fejlplaceringen jf. ovf. s. 72):

Mens min Broder han faldt til Ro, ${ }^{48}$ )
Jeg til Søes gjorde Gavn for To
Kaldes derfor og trindt om Land
Hothbrods og Hundings Bane-Mand.
Viser mange om mig er gjort
Derfor mit Ry blev tidlig stort.

Rimet om Helge, hvis fortsættelse altså er tilgængelig, er i sig selv ikke særlig værdifuldt, men et nyt udtryk for Grundtvigs fremgangsmåde ved gendigtning eller omdigtning af sagn. I anlægget ser han ganske bort fra rimkrønikens indledningssentens om straffen for ukyskhed, der forøvrigt er inspireret af Secreta Secretorum, og ligervis fra Helges blodskamstragedie og formentlige selvmord. Derimod praktiserer han, som i flere af de foregående rim, den metode han som ung havde lært af Suhms Historie af Danmark og J. B. Møinichens De nordiske Folks Overtroe, Guder, Fabler og Helte, indtil Frode den 7des Tider; $i$ Bogstavorden (1800), jf. Breve I (1924) s. 6. Den går kort og godt ud på at kombinere alle foreliggende traditioner for at opnå den fyldigst mulige historieskrivning. Som Suhms tilskud havde været Ossian, havde Grundtvigs i nogle af de foregående rim været Beowulf. I Helges rim er det dog en anden kilde: en som rimkrøniken vel har vraget, men dog en som har hjemmel hos Saxo, kvadet om Helge Hundingsbane. Af Grundtvig udvides benyttelsen med at Helge, som $i$ eddakvadet, dræbes af Hundings søn Dag.

${ }^{48}$ ) Ordspillet er typisk for Grundtvig. 
I de følgende rim synes det som Grundtvig har tabt kræfterne til at fortsætte som han havde begyndt. I forhold til den gamle krønike er det en vinding at Odin kommer før Balder, og Hother efter; men hvis Saxos værk medregnes, er udvidelserne små og ubetydelige. Måske stikker forskeren i Grundtvig en fod frem når han ser Hjartvars forræderi $i$ forlængelse af beretning om hundekongen som svenskerne skulle have sat over Danmark.

Som tidligere omtalt er der i Sv. Grundtvigs aftryk dækning til og med Fenge, Amlets stedfar, og derudover er der i fasc. 288 en side og to linjer om den berømte prins, som vel ikke adskiller sig enormt fra den gamle krønike, men dog har et vist egenværd i kraft af sin friskhed:

Amlet Horvendels Son.

Af egen Erfaring bedst jeg veed, At »Far i Mag« giør god Beskeed Hvor Man kan ei komme frem med Magt, Med Læmpe fuldtit Man naaer sin Agt. Jeg maatte vel klage paa stort Uskiel, Min Farbroder slog min Fader ihjel, Det Samme han havde og mig tiltænkt Og vilde mig for et godt Ord hængt, Hvis ikke jeg havde ladt med Flid, Som jeg var gaaet fra Sands og Vid. Min Moder hun tog det Skarn til Mand Og lod mig gaae for Lud og koldt Vand, Men Mod var der i mig usle Pog,

For alt som jeg sad i Aske-Krog

Da hitted jeg paa fuldsær en Leg

I Emmer jeg bagde Egen sei

Og gjorde mig Kroge velberaad,

Og trak forsynlig dem paa en Traad,

Og naar saa Nogen, der saa det Spil, Mig spurgde: hvad skal de Kroge til, Da svared jeg rask i Toppen rød, Med dem vil jeg hevne min Faders Død.

$\mathrm{Nu}$ Mange vel tog det kun for $\mathrm{V} 2 v^{48}{ }^{48}$ )

Men Fenge, for han var selv en Ræv, Og saae det helst, at jeg ilde foer, Han skrev bag Øre det lille Ord Og prøved med mig fuldmangt et Træk, Saa nødt jeg var til at spille Gizk, Naar jeg vilde frelse mit unge Liv, Der stod som paa Odden af en Kniv.

48) Herover overstreget: $\mathrm{Nu}$ Spot Man vel med den Tale drev, Men Fenge det dog bag Øret skrev. 
Som allerede sagt, er det ikke alverden der er omdigtet her. I rimkrønikens v. 475 taler Amleth om »At offuerse oc gaa fulsacth«, det er det Grundtvig i anden linje oversætter så mundret. I det hele taget er det variationerne der er hans styrke, således i det kvikke udtryk for Amleths mors ny ægteskab. Psykologisk er det fineste ny bidrag at Amleth bliver rød i toppen hvis han tror hævnplanerne gennemskuet, langt ud over middelalderligt mål, stilistisk det mærkværdigste at Grundtvig ved omdigtning (jf. note 49) skaber en syntaktisk enhed på 4 vers mod rimkrønikens gennemførte princip med 2.

Denne elegante afpudsning, uden saglige tilskud af betydning, er det tydeligste vidnesbyrd om at Grundtvig var gået i stå som gendigter af de gamle rim. Det kan derfor ikke undre at de tre udvalgte blandt de senere sagnkongerim der kom med, var svagt moderniserede optryk af den gamle krønike, ikke helt få rettelser kan endda spores i trykmanuskriptet!

Derfra springer han helt frem til Christian 1, hvor han utvivlsomt har følt at han gjorde en gammel gæld god igen. Det var jo egentlig meningen at Christians rim skulle have været med i DV I, ikke så meget for sin dyds skyld som for at vise at det stilistisk afveg fra de bedste af de ældre kongers. I 1834 er situationen imidlertid en anden: nu gælder det at vise hvad en medlevende skjald kan få ud af det, ganske som vi så det ved Skjolds. Vi har her foruden trykket og Collin 21965 vers midti i kladde i fasc. 389. Kladden afviger i tilsvarende detaljer som ved Skjold; i renskriften er rettelserne få, et godt tegn på at teksten i det væsentlige har ligget færdig i forvejen. Den friske fremstilling, som kun i hovedtræk svarer til originalen, peger i samme retning.

Der er næppe tvivl om at Grundtvig havde tænkt sig en ubrudt række af kongerim op til hans egen tid; men Hans og de følgende konger fik han ikke digtet om, og man undrer sig næsten over at han ikke har kunnet høre hvor stærkt det næste rim i NKT 1834, Frederik 3s, faldt uden for den gamle tone, lige fra den inversionsmættede begyndelse: „Død var Helten, brudt var Freden, / Tabt var Alt, paa Staden nær.« Det gælder ikke Christian 7s, hvis strofeform er så meget lettere på grund af de mange anapæster i begyndelsen af linjerne. At de mellemliggende rim udelodes, kan måske skyldes angst for den censur Grundtvigs skrifter i disse år var prisgivet; Frederik $4 \mathrm{~s}$ kommer i form og tone de gamle rim nærmest. Subjektivitet øjnes naturligvis nemmere her end ved de gamle rim, men samtidig afgiver de en nøgle for hvordan disse skal tolkes, med tydeligt indtryk af nationalbevidsthed og fyrstelig ansvarsfølelse, som 
i Peter den stores undren over at Frederik 4 ikke betragtede sig som herre over liv og død. De to grupper giver et ønskeligt helhedsindtryk af Grundtvigs forfatterskab, der dækker alt fra Humble og Skjold til den herskende drot.

At Grundtvig på sine gamle dage endnu engang har arbejdet aktivt med rimkrøniken, er først blevet kendt for tre år siden, da den daværende Vartov-bibliotekar, Hans E. Eriksen, hos en københavnsk antikvarboghandler fandt Grundtvigs håndeksemplar af $\mathrm{C}$. J. Brandts rimkrønikeudgave, med udgiverens dedikation fra april 1858. Det var 1872 gået over i Sv. Grundtvigs eje, og er nu blevet indlemmet i Vartovbiblioteket. Det er ikke givet at Brandt havde været glad for Grundtvigs rettelser i bogen, nydigtningerne havde han derimod nok ladet stå ved deres egenværd.

Ganske bortset fra Grundtvigs rettelser i det færdige arbejde, kan det ikke nægtes at Brandt som middelalderforsker var hemmet af sin mester, og at dette har svækket betydningen af det pionérarbejde han i virkeligheden udførte. Brandts Sverigesrejse 1851 er skelsættende i dansk middelalderforskning, fordi han var den første der dannede sig et klart overblik over den grundstamme af danske håndskrifter der er havnet på bibliotekerne i Stockholm og Upsala, i betragtning af den gamle danske litteraturs vilkår af omtrent samme betydning som de islandske håndskrifter $\mathrm{i}$ København. Sine vigtigste spor satte rejsen sig i en række udgaver, der endnu ikke har fundet afløsere, og hvis eneste alvorlige pletter er bemærkninger der tager afstand fra den katolske ånd og indflydelse i middelalder-litteraturen (jf. Christiern Pedersens Danske Skrifter II (1851) s. $486 \mathrm{ff}$. og Romantisk Digtning fra Middelalderen III (1877) s. 287 ff.).

I denne række gammeldanske skrifter ville han gerne indlemme Stockholmerhåndskriftet $\mathrm{K} 41$ - som tidligere i afhandlingen nævnt, i flere henseender den værdifuldeste tekst af rimkrøniken vi har; men foruden den sørgelige kendsgerning at det er et brudstykke, der begynder midt i Amleths og ender i begyndelsen af Valdemar atterdags rim, var der ved udgaven det tungtvejende hensyn at en rimkrønikeudgave for enhver pris skulle være en folkebog, altså upedantisk, så meget mere som Molbechs i sin tid var udsendt til en lukket kres ved subskription, og Leys folkeudgave fra 1841, som bl. a. havde vundet Grundtvigs bifald ved sin moderniserede stavning, var udsolgt; den tekstkritiske udgave af $\mathrm{K} 41$ som Brandt nok helst havde leveret, gennemførtes først et par generationer senere af Holger Nielsen. Man kan næsten sige det var Brandts ulykke at han ikke var så meget ældre at han kunne være kommet $i$ gang 
i 1810erne eller 20erne, da Grundtvig selv havde pionérånden og lysten til at styrte sig ud i de halvkendte, endnu uudforskede tekster. Men den Grundtvig der dengang havde været en hund efter at opspore varianter, var nu nået til et stadium hvor han holdt sig til én Vulgata-tekst, og lod den være god nok. Det stemmer godt hermed at han i stor udstrækning retter K 41-læsemåderne til Ghemens former; i de første 586 vers, hvor Brandt havde været nødt til at følge dennes tekst, er der kun én rettelse. En anden tendens i rettelserne går ud på at erstatte forældede ord med velkendte, f. eks. fyrme (skåne) i v. 1747 med frede.

Alt dette er imidlertid bagateller mod Grundtvigs positive indsats i denne bog: omdigtningerne, der begynder som mindre indgreb ved de første kristne konger, og kulminerer i et helt omtydet kongerim ved Valdemar sejr. Vi skal se på nogle karakteristiske tilfælde.

De små indgreb skyldes naturligvis ofte stilistisk behændighed, som vi i rigt mål kender den fra Grundtvigs ihærdige arbejde med Skjolds rim i 1834; men fra og med Erik barns rim er der ofte en dyb kilde $\mathrm{i}$ dem, som kunne begrunde et nøje gennemsyn af rettelser der ikke er bestemt af Ghemens varianter ${ }^{50}$ ), med henblik på den aldrende Grundtvigs teologi. For det første ændres i v. 2814 (Brandts udg. 2806) den kristne Vane (skik, kultus) til Bane, dernæst i det følgende vers Djævels (Magt) til Mørkets, hvad der viser at Grundtvig ikke bruger djævel som betegnelse for noget udenfor den kristne tro. Dette bekræftes i v. 2831 (2823): 》Mange fore der og Djævle fra«, hvor Grundtvig indsætter Trolde. I v. 2826 ændres Den helge Tro til og troens ord ${ }^{51}$ ), et godt eksempel på den vægt han lægger på trosmeddelelsen gennem den mundtlige forkyndelse. Endelig indpasses Grundtvigs tanke at sjælene er købt ved frelsen i v. 2830, hvor det i forbindelse med Ansgars folkedåb siges at den var tåbelig »Som saadan Naade sløpte《 (dvs. gav slip på): »som naade for ret ei kiøbder.

Fra Erik ejegods rim antager omdigtningerne et vældigt omfang; men ud over det kendte stilistiske formål at gøre krøniken læselig for en videre kres, går de mest $\mathrm{i}$ retning af at understrege kongens eller landets hæder. Det er først med Valdemar sejrs rim, og kun

50) Bestemt af Ghemens tekst er f. eks. rettelsen af »Han viste os den samme Gud« (v. 2825, Brandt 2817) til »Han viede os den sande Gud«.

51) I sine senere år anvendte Gr. i vid udstrækning små forbogstaver i substantiver til private notater i bøger. - For rimkrønikens vedkommende bruges i omtalen af Brandts bog den af ham anvendte stavemåde, mens verstal udenfor parentes fortsat er Ghemen-Molbechs. 
for alvor i det, at der sættes et helt nyt moment ind, og det er rimeligvis i bevidst polemik mod Holsteinische Reimchronik, som der jo ligger notater fra i fasc. 288, jf. ovf. s. 64 .

Rimkrønikens Valdemarsrim er et typisk »quod erat demonstrandum«. Ligesom i Knud den helliges er indledningssentensen taget fra Secreta Secretorums advarsel mod edsbrud, og udviklingen er følgerne af et sådant: når Valdemar kuldsejlede på magtens tinde, er der to grunde: den mindre graverende et galant æeventyr med grev Henriks gemalinde, og den utilgivelige at han brød sit edelige løfte ikke at søge hævn for sin tort. Det er denne redelige, dybt alvorlige fremstilling der har været den holstenske digter et kærkomment udgangspunkt; og havde den danske munkedigter anet sådant, havde han nok tilrettelagt sit rim anderledes. Derfor gør Grundtvig det nu på hans vegne, $i$ en ånd som stemmer med Ingemanns roman.

Advarslen mod edsbrud (v. 4042-47, Brandt et vers mere) erstattes med en drøftelse af Valdemars tilnavn, der ikke kendes i den gamle krønike, hvor han blot kaldes Knuds broder:

\author{
At det gaaer baade op og ned \\ med denne verdens herlighed \\ det maatte klart jeg friste \\ jeg var og kaldtes seierrig \\ men hvad jeg vandt i kamp og krig \\ jeg tabde paa det sidste.
}

Det næste større indgreb erstatter den kedsommelige skildring af dansk magtudvidelse i Balticum efter 1219 (v. 4111-16, Brandt 4115-20) med sagnet om Dannebrog:

\author{
Vel hardt det holdt, der gaaer af ry \\ men Seieren faldt dog ned fra sky \\ alt under dannebroge, \\ det hellige kors staaer deri hvidt \\ jeg tænker, der vindes seier tit \\ dermed paa danske toge.
}

Som tidligere nævnt, vil Grundtvig ikke vide af at Valdemar skulle have forført grev Henriks gemalinde, formentlig en dublet til sagnet om Erik glippings forhold til marsk Stigs hustru, men omdigter begivenhederne omkring tilfangetagelsen på Lyø til et skændigt forræderi, som kontrasteres det danske folks ædelmodighed ved indsamlingen af løsepengene (v. 4123-40, Brandt 4127-44, tegnsætningen her væsentlig suppleret): 
Grev henrik, som jeg med vold og magt

havde tvunget til trosskabseed og pagt,

han skulde min lensmand være,

han stjal sig paa mig hvor jeg paa jagt

paa lyø laa uden frygt og vagt,

han gjorde ret mod sin ære;

han tog baade mig og valdemar,

som min ældste søn og arving var,

han til Sverin os førde,

der lagde han os i baand og bast,

han fik derfor baade skam og last,

hvor man det rygte hørde.

Det beed dog ei paa den haarde knark,

han vilde have 40000 mark

for os i løsepenge,

dem maatte de ædle danske mænd

betale for at faae mig igien,

det skal vel mindes længe.

Ud for det følgende, om Valdemars løfte og løftebrud, med konsekvensen Bornhöwed, findes den samme lodrette streg som f. eks. ved Svend Estridsøn og hans sønner, der rimeligvis er et mærke med henblik på senere omdigtning; og det eneste epokegørende tilskud til resten af rimet gælder slutningsverset, som omformes til »og prøvet lykken tilfulde«« - mens det foregående rimord rettes til »under mulde«.

Knap så heldige virker omarbejdelserne i Margretes rim; men det skyldes måske at dette i slægtleddene efter Grundtvig har nået en folkeyndest der gør det sakrosankt. Det vil næppe være retfærdigt at citere nogen af rettelserne her, og det får blive ved det helt omarbejdede, i krøniken mærkværdigvis efterfølgende rim om Oluf, hvor Grundtvig lader forskellen på de arvede riger og det fremmede Sverige træde endnu tydeligere frem (v. 4777-84, Brandt 4781-88), og hvis eskatologiske perspektiv han giver en poetisk løftelse:

Jeg kun var Koning en stakket Stund ${ }^{52}$ ),

før jeg af Helsot døde,

mit Olavs-navn paa fremmed grund

i sverrig blev orme-føde,

det hviler nu der til den stæunedag

da skal tilfjelds det stige

og løftes i sky med skjoldebrag

i gamle norges rige.

52) Den uensartede ortografi skyldes at Brandts trykte former er bevaret. Rettelser i femte linje tyder på at den ikke har fået sin endelige form; i linje 4 står kun sver (foran det trykte). 
Unionskongernes rim pudser Grundtvig af flere steder. Som i de foregående mærker han i videst muligt omfang de upoetiske årstalsvers, formentlig som hjemfaldne til at slettes; og i Christoffer af Bayerns rim indføjer han for eneste gang ekstra handlingsvers, en udpensling af kongens kamp med de oprørske bønder, stoffet fra folkevisen om kong Christoffer og Henrik Tagesøn (DgF nr. 162). Her er Grundtvigs bidrag en tiltrængt indsprøjtning af liv.

Grundtvigs rimkrønikesysler spænder da fra 1815 til hans livs ende, og må i det meste af denne tid regnes for hans rigeste inspirationskilde. Mindst gælder dette begyndelsen af $1820 \mathrm{erne}$; af foredraget $i$ anledning af Leys udgave 1841 fremgår at han under syslerne med Saxo havde fået den noget på afstand, men fik den ind på livet igen da han fik Molbechs udgave i hænde. Det fremgår videre af denne tale at han foretrækker Leys folkelige optryk for Molbechs lærde, og at han selv så en fortjeneste i at sætte »Noget til af mit eget Fabrik« da han offentliggjorde sit udvalg i 1834. Denne indstilling har han senest fået i 1826, jf. udkastene til Skjolds rim og det trykte digt Broder Niels fra Soor; men det er ikke hvad han havde tænkt sig i første omgang da han optrykte udvalgte rim i DV I (1816), kun med tillempet retskrivning, og med grundige ordforklaringer. Det er en udvikling fra et filologisk standpunkt til et suverænt digterisk, det samme vi kender fra Nordens Mythologi 1832 (s. 416), hvor »det for os giør liden eller ingen Forskiel, hvad der svævede for Mythe-Smeden, naar kun hvad vi lægge i Mythen er godt at giemme, og ligger magelig i den «. Men da det reviderede standpunkt er tydeligt i rimkrønikesyslerne 1826, er det altså ikke noget 1832-skel!

Videnskabsmænd på de områder hvor Grundtvig efterhånden traf sine suveræne tolkningsvalg - om teologien må regnes med hertil, er jeg ikke kompetent til at afgøre - kan ikke undgå at udstøde hjertesuk på fagets vegne; men vil man forstå Grundtvig som digter og åndspersonlighed, er man nødt til at bøje sig for denne storladne mytiske etos, som har gjort hans forfatterskab klassisk. Og så må man i retfærdighedens navn ikke glemme at det var et bevidst valg Grundtvig traf, med en folkelig dansk renæssance for øje. Der kræves nogen medhu med skjalden for at begejstres af den, men en medhu som er betingelsen for at forstå hans digteriske indsats. Kommer man til ham fra de videnskabelige emner han behandler, kan sympatien somme tider svigte; men her har det tit været videnskabsmændenes fejl at de ikke har fulgt Grundtvig på de forberedende stadier - sådan som den moderne angelsaksiske filologi 
med Kemp Malone i spidsen har gjort det. Prøver man det, opdager man hvor mange af de historiske og filologiske problemer Grundtvig har tænkt igennem, og taget offentlig stilling til hvis lejlighed bød sig, for derefter at lægge dem til side for ikke at trætte en bredere læsekres, med hvad der i dens øjne måtte stå som pedanteri.

Det er rystelsen ved Kielerfreden som bitter afslutning på en række prøvelsens år der sætter de vidtrækkende historiske og filologiske studier i gang, hvis to altoverskyggende konsekvenser bliver kendskabet til Beowulf og rimkrøniken, og vigtigst af disse igen den sidste, som gav Danmark en kongeæt der nedstammede fra Jafet, og var eller kunne gøres til et spejl for vor historie og vort nationale præg. Han erklærede selv i 1834 at han kendte den bedre end sin bibel, og det vil sige en del! Af de gamle redaktioner huede Ghemens ham bedst, og han var overbevist om at Alborgfragmentet, der jo savner årstalsangivelse, var ældre end trykket fra 1495 , ja, at det eller en eventuel endnu aldre udgave var den forste bog der var udgået fra Ghemens presse. Man mindes her igen modsigelsens grundsætning, for det var Grundtvig om at gøre at bevise at denne danske bog var trykt i København før nogen latinsk. Det gjorde han ivrigt, både i sang og tale ved festen 24. juni 1840 i anledning af 400-års-jubilæet for bogtrykkerkunstens opfindelse (jf. Steen Johansens bibliografi II s. 165). Vi vil slutte denne redegørelse med de tre frejdigste strofer af sangen:

Han holdt nu Raad i Kiøbenhavn

Med alle dem, han kiendte,

Hvad allerførst til fælles Gavn

Med Flid han skulde prænte:

En raadte halvveis til Latin,

En Anden heelt og ganske,

En tænkte paa lidt Nyt fra Rhin,

Men Ingen paa det Danske.

Mens ivrig saa de skifted Ord,

Og det for Øren døve,

Tilbyes kom Broder Niels fra Soer,

Sin Lykke der at prøve;
Lidt hovedkulds han traadte ind

Til Prænteren nykommen,

Og trak et røget Kalveskind

Beskrevet op af Lommen.

Der rimet var om Hedenold,

Saa godt, man kunde samle,

Om Kongerne fra Dan og Skjold

Til Christian den Gamle,

Det var saa jævnt, det gik saa glat, At alle rgte Danske,

Som saae den Bog og fik den fat, Fik Lyst deri at granske. 